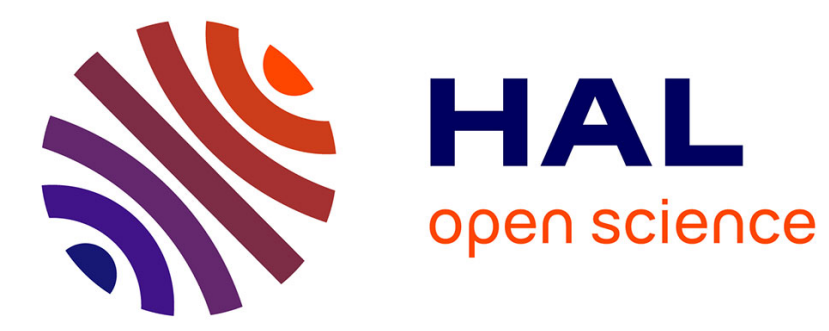

\title{
Innovation and exporting: evidence from Spanish manufacturing firms
}

Aida Caldera

\section{To cite this version:}

Aida Caldera. Innovation and exporting: evidence from Spanish manufacturing firms. Review of World Economics, 2010, 146 (4), pp.657-689. 10.1007/s10290-010-0065-7 . hal-00614170

\section{HAL Id: hal-00614170 https://hal.science/hal-00614170}

Submitted on 10 Aug 2011

HAL is a multi-disciplinary open access archive for the deposit and dissemination of scientific research documents, whether they are published or not. The documents may come from teaching and research institutions in France or abroad, or from public or private research centers.
L'archive ouverte pluridisciplinaire HAL, est destinée au dépôt et à la diffusion de documents scientifiques de niveau recherche, publiés ou non, émanant des établissements d'enseignement et de recherche français ou étrangers, des laboratoires publics ou privés. 


\title{
Innovation and Exporting: \\ Evidence from Spanish Manufacturing Firms
}

\author{
Aida Caldera* \\ ECARES, Université Libre de Bruxelles
}

April 25, 2010

\begin{abstract}
This paper investigates the relationship between innovation and the export behavior of firms using data from a representative panel of Spanish firms over 1991-2002. It presents a simple theoretical model of the firm decision to export and innovate that guides the econometric analysis. Consistent with the predictions of the theoretical model, the econometric results suggest a positive effect of firm innovation on the probability of participation in export markets. The results further reveal the heterogeneous effects of different types of innovations on the firm export participation. In particular, product upgrading appears to have a larger effect on the firm export participation than the introduction of cost-saving innovations. These findings are robust to firm unobserved heterogeneity, dynamic specifications, and to the use of instrumental variables to control for the potential endogeneity between innovation and exporting.
\end{abstract}

JEL no. F14, O31

Keywords: firm data, exporting, innovation, $\mathrm{R} \& \mathrm{D}$

*Please address correspondence to Aida Caldera, ECARES, Université Libre de Bruxelles, Av. F.D. Roosevelt 50, CP 114, 1050 Brussels, Belgium, T:+32-2-650-3075, F: +32-2-650-4475, acaldera@ulb.ac.be. 


\section{Introduction}

The recent trade literature has unveiled a large heterogeneity among firms that trade. Most of this literature has focused on the link between productivity and exporting and confirmed the empirical regularity that more productive firms self-select into export markets (e.g. Aw and Hwang 1995; Bernard and Jensen 1999, and for a recent literature review see Bernard et al. 2007). However, there is far less evidence on the role of innovation, one potential driver of productivity differences among firms (e.g. Griliches 1998) on the firm export behavior. A comprehensive study of the relationship between innovation and trade at the firm-level may improve our understanding of the drivers of firms' exporting decisions and the characteristics of firms that trade.

This paper aims at filling this gap by investigating the relationship between innovation and the export behavior of firms. It presents a simple theoretical model of the decision to export and innovate by heterogeneous firms which is based on the work by Bustos $(2005$; 2009) to guide the empirical analysis assessing the effect of innovation on firm export market participation. In the model firms are heterogeneous in terms of productivity and have the choice to invest in innovation to upgrade their technology. The model predicts that innovating firms are more likely to participate in exporting than non-innovating firms. Although innovating and non-innovating firms face similar fixed costs to access export markets, the innovating firms generate higher expected profits from exporting, that makes them more likely to export. I test this proposition for a panel of Spanish manufacturing firms over the period 1991-2002. There are several advantages of the unique dataset I use in the analysis. It contains not only the information on R\&D investments as more commonly available in the literature (see Aw et al. 2007 and 2009), but also the data on the output from the innovation process. In particular, the dataset contains time-varying information on product and process innovations of firms that allows a more precise investigation of different channels through which the innovation efforts are linked to the returns to exporting.

My empirical analysis confirms the theoretical predictions summarized above. The results suggest a positive effect of firm innovation on the probability of participation in export markets. Consistent with the theoretical predictions, firms that introduce cost-saving innovations are more likely to export than those firms that don't innovate. This result is in line with the theoretical intuition that innovating firms are more likely to export because they can charge lower prices and thus obtain higher returns from foreign sales than non-innovating firms. Also firms that innovate by upgrading their products or introducing completely new ones are more likely to export. This result supports the discussions in the previous literature indicating that product upgrading is an important component of firms' exporting decisions (Bernard and Jensen 2004; Iacovone and Javorcik 2008).

The empirical results further disclose the heterogeneous effects of different types of innovations on the firm export participation. The effects of product upgrading appear to weight more on the firm export participation than those of introducing cost-reducing innovations. In particular, the results indicate that current introduction of product innovations leads to greater probability of future exporting in the range of 2 to 16 percent depending on the econometric specification, while the effect of process innovation is by half smaller ranging between 1 to 8 percent, depending on the econometric specification. These results suggest that product upgrading gives a greater advantage to Spanish firms in export markets than the improvements in their production techniques. An interpretation of this result is that product upgrading allows firms to differentiate their products from rival firms, which may give a better advantage over competitors in export markets than cost-advantages gained though process innovation. These empirical findings are robust to alternative regression techniques to control for firm unobserved heterogeneity, an in particular to instrumental variables regressions to control for the potential endogeneity between innovation and exporting.

My study relates to the literature on trade and firm heterogeneity by investigating the role of firm 
innovation efforts on their export market participation. Clerides et al. (1998) and Bernard and Jensen (1999) were among the first to document the superior performance of exporters relative to purely domestic firms. Following their research, an extensive literature has reached the consensus that exporter premia can be explained by self-selection of best performers into export markets, rather than by learning by exporting. ${ }^{1}$ These empirical findings have been incorporated into theoretical models of trade that consider firm heterogeneity to explain differences in patterns of export participation as an interaction between firm productivity and fixed costs to export (Bernard et al. 2003; Melitz 2003; Yeaple 2005).

The importance of innovation for productivity and exporting of firms has been only recently brought into focus. A few empirical studies using micro-level data have documented a positive correlation between investment in R\&D and exporting (Aw et al. 2007; Bustos 2005 and 2009; Cassiman and Martínez-Ros 2005; Girma et al. 2008; Iacovone and Javorcik 2008; Lileeva and Trefler 2007). And only since very recently, a few theoretical papers have formalized the potential linkages between firm productivity, export decisions and R\&D efforts (Aw et al. 2009; Constantini and Melitz 2008). In particular, in a recent paper Aw et al. (2009) develop a structural model of the firm decision to invest in R\&D and participate in the export market and estimate the model using plant level data for Taiwan. They find that the selfselection of high productivity plants is the main driver of the decision to export and to undertake R\&D. Their study suggests further that both $R \& D$ and exporting have a positive effect on the plant's future productivity. However, they find little effect of investments in R\&D on the export decision once they control for the initial productivity differences.

In particular, my paper contributes to the above literature by investigating the effect of firm innovation activities on its export market participation. To characterize the linkages between the export and innovation decisions of firms, I derive a theoretical trade model of heterogenous firms that builds on the work of Bustos' $(2005 ; 2009)$ and test its implications using a sample of Spanish manufacturing firms. The main prediction of the model is that firms that innovate will also be more likely to export. The empirical analysis investigates in depth this proposition by relating firm innovation in terms of R\&D investments (both internal and contracted) and the introduction of new processes and products to its export participation decision. ${ }^{2}$ By contrast to other studies that assess the effect of R\&D on exporting (e.g. Aw et al. 2007 and 2009), my data allows me to empirically investigate the effect of actual innovation rather than $R \& D$ investments on the exporting decisions of firms. As such this study assesses the heterogenous effects of different types of innovations on the export decisions of firms.

There are some previous studies analyzing the exporting activities of Spanish firms. Cassiman and Martínez-Ros (2005) have also studied the link between innovation and exporting for the Spanish case, while Fariñas and Martín-Marcos (2007) have documented the superior performance of exporters versus non-exporters. Relative to these studies, this paper contributes to the understanding of the Spanish economy by documenting systematic and significant differences between exporters and non-exporters in terms of innovation efforts and outcomes. It also shows that previous innovation contributes to explain the heterogenous participation of Spanish firms in foreign markets, and that these results appear to be robust to a careful consideration of the econometric problems that concern the investigation of the link between innovation and exporting at the firm-level, such as unobserved heterogeneity, endogeneity and dynamic considerations.

The remainder of the paper is organized as follows. Section 2 presents the theoretical framework. Section 3 presents the preliminary evidence and provides an overview of Spanish firms' innovation and

\footnotetext{
${ }^{1}$ Evidence in favour of self-selection of better performing firms into export markets is provided by Clerides et al. (1998) for Colombia, Mexico and Morocco; Bernard and Jensen (1999) for the US; and Delgado et al. (2002) for Spain. Some papers find evidence of learning by exporting including Van Biesebroek (2006) for Côte-d'Ivoire and De Loecker (2007) for Slovenia. For a review of this literature see Greenaway and Kneller (2007) and Wagner (2007).

${ }^{2}$ The paper does not explore the effects of other sources of knowledge acquisition such as acquired technology or purchases of technology from abroad on exporting, which may arguably be also important for Spanish firms.
} 
exporting activities during 1991-2002. Section 4 describes the empirical strategy to estimate the effect of innovation on firm export market participation. Section 5 presents the econometric results and discusses the sensitivity checks. Section 6 concludes.

\section{Theoretical Framework}

This section presents a simple theoretical model of the decision to export and innovate by heterogenous firms to give intuition in support of the empirical analysis of the effect of innovation on firms' exporting decisions. The model builds on the work of Bustos (2005; 2009) who extends the Melitz (2003) model of heterogenous firms to include the possibility that firms make investments in innovation to reduce their marginal costs of production and upgrade their technology. I extend Bustos $(2005 ; 2009)$ model by developing the predictions of Bustos' model and directly comparing the exporting decisions of an innovating firm versus a non-innovating one, to make it empirically tractable. In this setting firms are heterogenous in productivity, so that more productive firms have an advantage over less productive firms, for example inherent to their managerial ability. Firms have the choice to invest in innovation, which implies incurring a fixed cost that brings a lower marginal cost of production. Only the most productive firms will find it profitable to incur the fixed cost of innovation because the increase in revenues implied by a reduction in marginal costs will be higher the higher is the initial level of productivity.

The main outcome of the model is that firms that innovate will also be more likely to export. The reason is that innovators find exporting more profitable than non-innovators: as innovators have lower marginal costs of production, they can charge a lower price which will increase total sales more than proportionally because demand is assumed to be elastic.

\subsection{Setup of the Model}

\subsubsection{Demand}

The demand side of the economy is modelled following the standard set-up used in recent trade literature (Bernard et al. 2003; Melitz 2003). Demand is characterized by a representative consumer with CES preferences over a continuum of varieties $i$ of a good $q$.

$$
U=\left[\int_{0}^{N} q(i)^{\rho} d i\right]^{1 / \rho} \text { where } 0<\rho<1 \text { and } i \in(0, N)
$$

In line with that literature it is assumed that consumers maximize their utility subject to the budget

constraint: $\int_{0}^{N} p(i) q(i) d i=E$, where $E$ is aggregate expenditure. Total demand for variety $i$ can be then written as:

$$
q(i)=\frac{E}{P}\left(\frac{p(i)}{P}\right)^{-\sigma}
$$

where $\sigma=1 /(1-\rho)>1$ is the constant elasticity of substitution across varieties, which also equals the elasticity of demand $\eta$ when the number of varieties $N$ is large, and $P=\left[\int_{0}^{N} p(i)^{1-\sigma} d i\right]^{\frac{1}{1-\sigma}}$ is the price index, as in Bustos $(2005 ; 2009) .^{3}$

\footnotetext{
${ }^{3}$ For the case of many varieties $N$ the firm $i^{\prime} s$ market share $s_{i}$ is small and the elasticity of demand $\eta$ is equal to the elasticity of substitution $\sigma: \eta=\sigma-s_{i}(\sigma-1)$ because it is generally assumed that an individual firm $i$ market share $s_{i}$ is small so the second term becomes negligible.
} 


\subsubsection{Supply}

The supply side of the economy is characterized by a monopolistically competitive industry, where each firm produces a single variety $i$ of good $q$ and there is free entry into the industry. Firms are heterogenous in an underlying productivity parameter as in Melitz (2003), denoted by $\varphi_{i}$, with more productive firms having a lower marginal cost of production and producing more output per unit of input. As in Melitz (2003) to enter the industry firms pay a fixed cost and draw their productivity from a known Pareto cumulative distribution function $G(\varphi)=1-\varphi^{-k}$ with $k>1$. After observing their productivity firms decide whether to exit, or to stay and produce. Following closely Bustos (2005; 2009), surviving firms have the choice between two production technologies: either they can choose to innovate to decrease the marginal costs of production and improve their production process, or stay as they are. Then in this set-up there is a part of productivity that is due to luck, but firms can also improve their productivity by investing in innovation. Firms that choose to innovate $\{I=1\}$ need to incur a fixed cost $f_{I=1}$, which is higher than the fixed cost of firms that choose not to innovate $\{I=0\}$ need to incur $\left(f_{I=1}>f_{I=0}\right)$ to keep the current level of technology, but innovation leads to lower marginal costs of production $c_{I=1}<c_{I=0}$.

Firms make a price and innovation choice that maximizes their profits. With CES preferences the profit maximizing price $\left(p^{I}\right)$ is a constant markup over marginal cost $\left(c_{I}\right)$, expressed more formally as:

$$
p^{I}\left(\varphi_{i}\right)=\frac{1}{\rho} \frac{c_{I}}{\varphi_{i}}
$$

Following Bustos $(2005 ; 2009)$ the quantity sold $\left(q^{I}\right)$ the revenues $\left(r^{I}\right)$ and the profits $\left(\pi^{I}\right)$ are defined by the following equations:

$$
\begin{gathered}
q^{I}\left(\varphi_{i}\right)=E P^{\sigma-1}\left[\rho \frac{\varphi_{i}}{c_{I}}\right]^{\sigma} \\
r^{I}\left(\varphi_{i}\right)=p^{I}\left(\varphi_{i}\right) q^{I}\left(\varphi_{i}\right)=E\left[P \rho \frac{\varphi_{i}}{c_{I}}\right]^{\sigma-1} \\
\pi^{I}\left(\varphi_{i}\right)=\frac{1}{\sigma} r^{I}\left(\varphi_{i}\right)-f_{I}
\end{gathered}
$$

For the purpose of my research question I slightly modify the Bustos (2005; 2009) set-up to compare the exporting decision of firms that innovate versus those that do not.

\section{Innovation decision}

Firms will choose to innovate $\{I=1\}$ as long as the profits from innovating $\left(\pi^{I=1}\right)$ will exceed the non-innovating profits $\left(\pi^{I=0}\right)$, which can be formally expressed as:

$$
\pi^{I=1}\left(\varphi_{i}\right)>\pi^{I=0}\left(\varphi_{i}\right) \Longleftrightarrow \frac{1}{\sigma} E\left(P \rho \varphi_{i}\right)^{\sigma-1}\left(c_{I=1}^{1+\sigma}-c_{I=0}^{1+\sigma}\right)>\left(f_{I=1}-f_{I=0}\right)
$$

Taking into account the analysis of firms' profits and cost functions the above expression shows that firms will innovate when the benefits from innovation, the left hand-side of the equation, are larger than the costs from innovation, the right hand side of the equation. Expression (7) suggests that there will be a self-selection of the more productive firms into the decision to innovate as the benefits from innovation are an increasing function of firm productivity $\varphi_{i}$. More productive firms (larger $\varphi_{i}$ ) will invest in innovation because the increase in revenues from a reduction in marginal costs will be higher the higher is productivity $\varphi_{i}$.

\section{Export decision}

After entry and making the innovation choice, in addition to serving the domestic market, firms also have the choice to export. International trade is costly and in order to export firms need to bear two 
types of trade costs: a fixed cost to export $f_{x}$ and a variable unit cost that takes form of an iceberg transport cost, so that for a unit of good to arrive, $\tau>1$ need to be shipped. The fixed export cost can be interpreted as distribution and servicing costs in the foreign market. The export profits can be expressed as:

$$
\pi^{* I}\left(\varphi_{i}\right)=\tau^{1-\sigma^{*}} E^{*}\left(P^{*} \rho^{*}\right)^{\sigma^{*}-1} \frac{1}{\sigma^{*}} c_{I}^{1-\sigma^{*}} \varphi_{i}^{\sigma^{*}-1}-f_{x}
$$

where $E^{*}$ is foreign spending in good $q, P^{*}$ is the price index in the foreign country, $f_{x}$ is the fixed cost to export, and firms may face a different elasticity of demand in the domestic $\sigma$ and foreign market $\sigma^{*}$, where $\rho^{*}=\frac{\sigma^{*}-1}{\sigma^{*}} .4$

\section{Proposition: Innovators are more likely to export than non-innovators.}

This proposition follows from comparing the increase in total profits from exporting for an innovator to the increase in total profits from exporting for a non-innovator. A firm will export if the profits from the domestic market and exporting are jointly larger than the profit from serving only the domestic market:

$$
\left[\pi^{I}\left(\varphi_{i}\right)+\pi^{* I}\left(\varphi_{i}\right)\right]>\pi^{I}\left(\varphi_{i}\right)
$$

Then an innovator will choose to export if

$$
\left[\tau^{1-\sigma^{*}} E^{*}\left(P^{*} \rho^{*}\right)^{\sigma^{*}-1} \frac{1}{\sigma^{*}} \varphi_{I=1}^{\sigma^{*}-1}\right] c_{I=1}^{1-\sigma^{*}}>f_{x}
$$

while a non-innovator will choose to export if

$$
\left[\tau^{1-\sigma^{*}} E^{*}\left(P^{*} \rho^{*}\right)^{\sigma^{*}-1} \frac{1}{\sigma^{*}} \varphi_{I=0}^{\sigma^{*}-1}\right] c_{I=0}^{1-\sigma^{*}}>f_{x}
$$

Comparing Eqs. (10) and (11), the variable profits from exporting, the left hand side of Eqs. (10) and (11), are larger for an innovator than for a non-innovator, while the fixed cost to export $\left(f_{x}\right)$ is the same for both types of firms. This is because the productivity of an innovator is higher than the productivity of a non-innovator $\left(\varphi_{I=1}>\varphi_{I=0}\right)$, while its marginal costs are lower $c_{I=1}<c_{I=0}$. Note that the causal link is from productivity to innovation and from innovation to exporting. The intuition for this result is as follows. As explained above, more productive firms choose to innovate. By investing in innovation innovators achieve a lower marginal cost of production than non-innovators $c_{I=1}<c_{I=0}$. For that reason innovators can charge a lower price than non-innovators, which will increase their total sales more than proportionally because demand is assumed to be elastic. This result will always hold since the productivity of a firm that chooses to innovate is strictly higher than the productivity of a non-innovating firm, because by definition the innovating firm can profitably cover the higher fixed costs to innovate $\left(f_{I=1}>f_{I=0}\right)$ as given by Eq. $(7) .^{5}$

To finalize the model I characterize the productivity thresholds that define firms' exporting and innovation decisions. As shown by Bustos (2005), there are two possible productivity configurations depending on the size of the fixed innovation cost compared to the size of the fixed export cost. If the fixed costs to innovate are sufficiently higher than the fixed costs to export $\left[\left(f_{I=1}-f_{I=0}\right)>f_{x}\right]$, then the minimum productivity level needed to innovate without incurring negative profits is higher than the minimum productivity level needed to export profitably, i.e. $\varphi_{x}<\varphi_{I=1}$. In this case innovators will export, and there will exist some middle productivity firms that do not innovate but manage to cover the fixed costs to export. The other possible configuration is that $\varphi_{x}>\varphi_{I=1}$ that occurs when the fixed

\footnotetext{
${ }^{4}$ I would like to thank one of the referees for suggesting to consider different demand elasticities for the domestic and export market.

${ }^{5}$ Figure 1 panel A shows that the data supports this assumption. The figure shows that the productivity distribution of innovating firms lies to the right of the productivity distribution of non-innovating firms, suggesting that innovators are more productive as assumed by the theoretical model.
} 
costs to export are sufficiently higher than the fixed costs to innovate $\left[\left(f_{I=1}-f_{I=0}\right)<f_{x}\right]$. In this case only innovators will export, while non-innovators will only serve the domestic market. ${ }^{6}$

If $\left[\left(f_{I=1}-f_{I=0}\right)>f_{x}\right]$, then firms can be classified into three groups according to their productivity level: high productivity firms which innovate and export $\left(\varphi_{i}>\varphi_{I=1}\right)$; medium productivity firms which do not innovate but export $\left(\varphi_{x}<\varphi_{i}<\varphi_{I=1}\right)$; and low productivity firms which don't innovate and serve only the domestic market $\left(\varphi_{i}<\varphi_{x}\right)$.

In the next section, I present the firm-level data that will be used to test the prediction of the model that firms that innovate are more likely to export. The section describes the statistical evidence and provides an overview of Spanish firms' innovation activity and exporting behavior for the panel of 19912002. It also provides preliminary empirical evidence on the positive relationship between innovation and exporting, which motivates further the econometric analysis.

\section{Innovation and Exporting of Spanish Firms}

\subsection{Data}

This study uses annual firm-level survey data for the period 1990-2002 compiled from the Encuesta Sobre Estrategias Empresariales (ESEE). The ESEE survey is sponsored by the Spanish Ministry of Industry and includes the balance-sheet data and information on firm strategies for a representative sample of Spanish manufacturing firms. In the first year of the survey in 1990, firms were chosen according to a selective sampling scheme with different probabilities of participation depending on firm size. All firms with more than 200 employees were asked to participate, and about $60 \%$ of all firms of this size category answered. Firms that employed between 10 and 200 employees were sampled randomly by industry and size strata, and the rate of participation was about $4 \%$. To preserve the representativeness of the sample, the initial characteristics of the survey have been maintained in subsequent years. Newly created firms have been added to the survey every year and exits of firms have been recorded (for more details on the survey design see Fariñas and Jaumandreu, 1999). After the cleaning process described in more detail in the Appendix, the unbalanced panel of firms used in this study includes on average 1,890 firms with a total number of 21,949 observations over the period 1991-2002. ${ }^{7}$

This dataset is unique in providing information on the inputs and outputs of firms' innovative activities. In particular, I observe each firm's participation in R\&D activities, R\&D expenditures, and introduction of product and process innovation in each year. Moreover, the dataset includes yearly information on each firm's export sales. Given the richness of the ESEE data, I can estimate directly the effect of different types of innovative activity on the exporting behavior of firms, without solely relying upon the input measures of the innovation process. Before turning to the econometric analysis in Section 4, I first statistically describe the data and document the link between innovative activity and exporting of Spanish firms.

\subsection{Participation of Firms in Innovation and Exporting}

I first provide a snapshot into the panel dimension of the dataset. Table 1 documents the distribution of firms across different years according to their status of innovation and exporting. A firm is classified as

\footnotetext{
${ }^{6}$ The data does not support this case as we observe that about $60 \%$ of firms export compared to only about a third of them that innovate, which tends to suggest that the fixed costs to innovate are higher than the fixed costs to export. Therefore in the descriptive statistics that follow I will focus on the case where $\left[\left(f_{I=1}-f_{I=0}\right)>f_{x}\right]$.

${ }^{7}$ The data used in this study has been previously used by Delgado et al. (2002) to study the productivity of exporting firms and Fariñas and Ruano (2005) to study firm heterogeneity and market selection. The data is cleaned with respect to unlikely values and large spikes in the variables used in the empirical analysis. The first year of the sample is lost because there is no data available for capital necessary to construct productivity. Due to this cleaning less than $2 \%$ of the observations are lost, so the sample remains highly representative.
} 
innovating, if it reports positive R\&D expenditures. Similarly, an exporter is a firm that reports positive export sales.

\section{[Insert Table 1]}

Table 1 shows that on average almost two thirds (60\%) of firms exported during 1991-2002. The share gradually increased over time and while it represented $51 \%$ of firms in 1991, it rose to $64 \%$ in 2002 .

Among all firms, only about one third $(37 \%)$ of them innovate. The R\&D intensity is also very low as observed in the last column of Table 1, which reports the average R\&D intensity measured as the ratio of $R \& D$ expenditures to sales by year. In particular, the average R\&D intensity was only $0.59 \%$ during 1991-2002. This descriptive micro-evidence is hardly surprising, as it is largely in line with the aggregate figures on the low R\&D intensity of the Spanish economy. For instance, business R\&D statistics published yearly by the OECD show that Spanish business R\&D spending relative to value-added was only $0.70 \%$ compared to the average values of $1.65 \%$ for the EU25 and $2.13 \%$ for the total of OECD countries during 1998-2002 (OECD 2004: Table 26).

I take a closer look at the sectoral composition in Table 2. The ESEE dataset covers all manufacturing sectors and Table 2 presents the fraction of exporting and innovating firms over all firms in each sector over the sample period. Sectors are classified according to their R\&D intensity based on the firm-level data and compared to the OECD classification based on the industry aggregate data.

\section{[Insert Table 2]}

Table 2 documents that exporting is quite common within most sectors. The lowest export participation is in the publishing and printing industry, and still the participation is rather high with more than one third of firms exporting in a given year (37\%). By contrast the participation in innovation is less frequent for each and every sector. As expected the innovation rates are high in high-technology sectors, where innovation is particularly important to face competitive pressures and retain market shares, compared to low-tech ones. For instance, in the chemical industry, which is known for its heavy reliance on basic research, around $70 \%$ of firms innovate in a given year. In contrast, in the low-tech sectors only one fourth of all firms (24\%) innovate each year.

\subsection{Differences between Exporters and Non-Exporters in Innovation}

In this sub-section, I compare exporters to non-exporters with respect to their innovation and other characteristics. This exercise is important to confirm whether there is a positive correlation between innovation and exporting at the firm-level as suggested by the theoretical model in Section 2.

\section{[Insert Table 3]}

I first compare exporters to non-exporters in terms of average innovation in Panel (A) of Table 3 over the sample period 1991-2002. Exporters are remarkably more innovative than non-exporters. Within the exporters, the share of innovating firms (53\%) is four times larger than the share of innovating firms within non-exporters (13\%). Exporters also have higher inputs into innovation process $(0.83 \%)$, as they spend four times more on R\&D than non-exporters (0.25\%). Henceforth, a larger share of exporters introduce product $(36 \%)$ and process $(43 \%)$ innovations relative to non-exporters (13\% for product and $23 \%$ for process innovation). Comparing the initial, middle and final sample year, the gap in innovation activity between exporters and non-exporters is substantial and very stable across time and measures of innovation - the percentage of innovating firms, R\&D intensity and the share of firms that conduct product or process innovations - as illustrated by the figures across three different time horizons further reported in Panel (A) of Table 3 . 
Next, I conduct a more formal test to assess the differences in innovation between exporters and non-exporters. For that purpose, I draw on the empirical approach used by Bernard and Jensen (1999) to estimate the exporter premia of US firms in terms of productivity and estimate the exporter premia in terms of innovation from the following panel fixed-effect regression:

$$
\ln \left(Z_{i t}\right)=a_{i}+b Y_{i t}+c \ln \left(e m p_{i t}\right)+d Y_{e a r_{t}}+e \operatorname{Ind}_{j}+e_{i t}
$$

where $Z_{i t}$ denotes the vector of characteristics of firm $i$ at year $t$, including sequentially the firm's measures of innovation, size, productivity, input costs and capital intensity. The variable $Y_{i t}$ is a dummy variable equal to 1 , if a firm $i$ exports and zero otherwise, emp $i$ is the number of employees working in firm $i$ at year $t$, and $Y e a r_{t}$ and $I n d_{j}$ are year and industry dummies. The exporter premium is captured by the coefficient $b$ that measures the percentage difference between exporters and non-exporters with respect to innovation activity or other firm characteristics captured by $Z_{i t}$.

Panel (B) of Table 3 presents the estimation results from equation (12). The results support the previous statistics from Panel (A) of Table 3, that is, exporters are on average more innovative than nonexporters. Exporters are 15\% more likely to innovate than non-exporters, spend 19\% more in innovation, $13 \%$ and $7 \%$ more of exporters introduce product and process innovations than non-exporters during 1991-2002.

Exporters appear to be significantly different from non-exporters with respect to other firm characteristics as well. Panel (B) of Table 3 further shows that Spanish exporters are on average twice larger, more productive (7\%), pay higher wages (11\%) and are more capital intensive (40\%) than non-exporters. These figures are in line with the estimates of exporter premia previously reported by Fariñas and MartínMarcos (2007) for Spain. And are also in line with the findings of Bernard and Jensen (1995; 1999) for the US, Bernard and Wagner (2001) for Germany, and De Loecker (2007) for Slovenia among others (For a review of this literature see Wagner (2007).

\subsection{Evidence on Productivity Ordering}

The theoretical model outlined in Section 2 gives insights into the productivity ordering we can expect from the data according to firms' status of exporting and/or innovating. To investigate whether these predicted productivity orderings are confirmed by the data, I compute firm-level productivity and compare different groups of firms classified according to their innovation and export status with respect to their productivity.

I estimate total factor productivity (TFP) using the firm-level data drawn from the ESEE. The firm $\mathrm{i}$ technology at time $\mathrm{t}$ is described by a Cobb-Douglas production function of the following form where all variables are expressed in natural logarithms:

$$
y_{i t}=\beta_{0}+\beta_{l} l_{i t}+\beta_{m} m_{i t}+\beta_{k} k_{i t}+\varepsilon_{i t}
$$

The dependent variable $y_{i t}$ is real output at the firm-level, deflated by individual output price indices for each firm constructed based on information drawn from the ESEE; $l_{i t}$ is the log of the number of employees; $m_{i t}$ is the log of materials deflated by individual intermediate inputs price indices for each firm constructed based on information drawn from the ESEE, and $k_{i t}$ denotes the log of capital measured by total fixed tangible assets deflated by capital deflator and $\varepsilon_{i t}$ is the residual. An important advantage of the data used in this paper is that it contains firm-level information on variation of output and intermediate input prices. This allows to compute real/physical output $\left(y_{i t}\right)$ by deflating nominal output with individual firm-output price index and circumvent the bias introduced by deflating nominal firm-level output by industry wide price indices, which is a common approach in the literature because 
firm-level data on prices are rarely available (See Klette and Griliches 1996 for a discussion of these issues and Mairesse and Jaumandreu 2005 for a comparison of estimates with wide industry deflators and firm-level deflators using the same data as in this paper).

As a baseline model to estimate equation (13) I use the Olley and Pakes methodology (1996). This estimation procedure is standard in the recent trade literature (De Loecker 2007; Konings and Vandenbussche 2008). The Olley and Pakes method takes account of the simultaneity between input choice and productivity shocks as well as sample selection bias (See Ackenberg et al. 2008; Van Beveren 2007; Van Biesebroeck 2007 for a discussion of these biases). ${ }^{8}$ I estimate the production function given by Eq. (13) for firms in each 2-digit sector separately. Table 4 reports the estimates of equation (13) using the Olley and Pakes (1996) method together with the OLS estimates for comparison. In line with priors, the labor and materials coefficients tend to be typically overestimated with OLS in most sectors in Table 4, while the capital coefficient tends to be underestimated. Using the estimates of the coefficients of the production function, the log of TFP of firm $i$ at time $t$ can be calculated as the residual of the production function:

$$
t f p_{i t}=y_{i t}-\widehat{\beta}_{l} l_{i t}+\widehat{\beta}_{m} m_{i t}+\widehat{\beta}_{k} k_{i t}
$$

Figure 1 plots the distribution of average total factor productivity for different groups of firms across all sectors in 2002. The first panel (A) plots the distribution of productivity for the group of firms that report to do R\&D (innovators) versus the group of firms that report not to do any R\&D (non-innovators). The figure shows that the productivity distribution of innovators is to the right of non-innovators indicating that on average firms than spend in $R \& D$ are more productive than those that do not. This is in line with the theoretical model which suggests that innovators will be generally more productive than non-innovators if there are some fixed costs to innovate.

\section{[Insert Table 4 and Figure 1]}

The second panel (B) of Figure 1 compares the distribution of productivity for exporting and nonexporting firms. As expected from the theoretical model the figure shows that more productive firms export: the productivity distribution of exporters lies clearly to the right of that of purely domestic firms. In the light of the theoretical model and Melitz's (2003) model, exporters are more productive than domestic firms because they are able to cover the fixed costs to export compared to less productive firms.

Finally, the theoretical model suggests a third productivity ordering with productivity being the highest for firms that do both innovate and export, intermediate for firms that export but do not innovate, and the lowest for firms that do neither of the activities. The third panel (C) of Figure 1 supports this intuition. It clearly shows that there are two distinct groups of firms in the population. On the one hand, innovating exporters appear to have the highest productivity, while on the other hand noninnovating domestic firms appear to have the lowest productivity levels. In between both groups of firms, the productivity distribution of domestic-innovators and non-innovating exporters tends to overlap. The theoretical model suggests that if the costs to innovate are higher than the costs to export, we would expect domestic innovators to have higher productivity than non-innovating exporters. The figure, however, shows that the productivity distributions of both groups tend to overlap, which suggests that on average firms in these groups appear to be similar in terms of productivity.

In conclusion, the descriptive statistics presented above are in line with the predictions of the theoretical model and clearly show a positive relationship between firms' innovative activities and exporting

\footnotetext{
${ }^{8}$ The Olley and Pakes (1996) methodology controls for the endogeneity in input choice by using the firm investment decision to proxy for unobserved productivity shocks and for firm survival introducing a survival rule into the estimation method. The endogeneity of input choice and the selection bias are well-known to the literature and have been documented extensively. For a review of the main methodological issues see Ackerberg et al. (2008).
} 
behavior. Based on the descriptive statistics and the exporter premia regressions, exporters appear to be significantly more innovative than non-exporters. Also the model finds support in the data with respect to the various productivity ordering across the different groups of firms. In what follows, I investigate more formally the positive relationship between innovation and exporting, using regression analysis to investigate the effect of innovation on the probability of exporting controlling for other potential determinants of exporting including differences in productivity across firms. In addition, I also assess the heterogenous effects of different types of innovation on firms' export decisions.

\section{Empirical Analysis}

In this section I define the empirical approach to test the main prediction of the theoretical model that firms that innovate are more likely to export. To verify this theoretical implication, I estimate a reduced linear version of the export participation choice described by equation (9) following a similar approach as Roberts and Tybout (1997) and Bernard and Jensen (2004). Following the description of the theoretical model in Section 2, a firm will decide to export $\left(Y_{i t}=1\right)$ if profits made by exporting exceed the profits from serving only the domestic market $\left(\pi_{i t}^{*}>0\right)$. This condition can be specified formally as the following binary choice model of export market participation, where the export profits of firm $i$ at time $t \pi_{i t}^{*}$ are expressed as a reduced function of the firm's and market characteristics:

$$
\begin{array}{lll}
Y_{i t}=1 \text { if } & \pi_{i t}^{*}=\beta I_{i t}+\alpha T F P_{i t}+\gamma Z_{i t}+\eta_{t}+\rho_{j}+\underbrace{u_{i}+\omega_{i t}}_{\varepsilon_{i t}}>0 \\
Y_{i t}=0 & \text { otherwise }
\end{array}
$$

where $Y_{i t}$ denotes the export status of firm $i$ at time $t$, taking the value 1 when the firm exports and 0 otherwise. Following Eq. (8) the main determinants of exporting are the firm productivity, denoted by $T F P_{i t}$, and the firm innovation activity denoted by $I_{i t}$. The coefficient of main interest $\beta$ measures the effect of innovation on the firm export status $\left(Y_{i t}\right)$. Following the intuition provided by Eqs. (10) and (11) in the theoretical model, innovating firms are expected to produce at lower marginal costs, and consequently to have higher expected profits. This would be reflected in a positive and significant $\beta$ coefficient indicating that firms that innovate are more likely to export. In addition, the firm exporting decision crucially depends on the level of firm's productivity, $T F P_{i t}$. As the theoretical model suggests, most productive firms self-select into the decision to export, which would be captured by a positive and significant effect of productivity on exporting, $\alpha>0$. The vector $Z_{i t}$ further denotes other firm characteristics influencing export profits and thus the firm decision to export, such as for example firm's size or age. The variable $\eta_{t}$ is a time specific-component that takes into account business cycles and macroeconomic effects that could affect the export decision in the model. The variable $\rho_{j}$ is a sectorspecific component that measures differences across sectors in terms of technological capabilities or export market opportunities. The remaining error term $\varepsilon_{i t}$ is made up of two components: $u_{i}$ is a firm-specific effect which captures time-invariant unobserved firm heterogeneity (such as managerial ability) that may affect the export decision; and $\omega_{i t}$ is an unobserved shock. This last term can be rationalized as demand or profit shocks in the export market that are not observed by the econometrician but may affect the firm decision to export in a given year.

\subsection{Baseline Econometric Model}

The baseline econometric model follows from equation (15). It is defined as a random effects probit model with variables expressed in logarithms and specified as: 


$$
\begin{gathered}
P\left(Y_{i t}=1\right)=\Phi(\beta I_{i t-1}+\alpha T F P_{i t-1}+\gamma Z_{i t-1}+\phi Y_{i t-1}+\rho_{j}+\eta_{t}+\underbrace{u_{i}+\omega_{i t}}_{\varepsilon_{i t}}) \\
\text { where } \omega \sim N(0,1) \text { and } u \sim N\left(0, \sigma_{u}\right)
\end{gathered}
$$

The subscript $i$ indexes firms and the subscript $t$ time. $Y_{i t}$ is a binary variable equal to 1 if the firm exports in $t$ and 0 otherwise. $I_{i t-1}$ is a variable measuring firm innovation activities. As will be explained in the following subsection, I use different measures of firm innovation activities that capture both the inputs from firm innovation activities, such as R\&D expenditures, and more direct measures of innovation outputs, such as process and product innovations. Firm-level productivity is measured by total factor productivity, $T F P_{i t-1}$.

The rest of the explanatory variables included in the vector $Z_{i t-1}$ control for a set of firm characteristics, which have been shown in the statistical comparisons of exporters and non-exporters in Section 3 to likely to be related to export behavior. Size $i t-1$ represents the size of the firm $i$ at time $t-1$ measured in terms of the total number of employees. Age $e_{i t-1}$ measures firm's $i$ experience in terms of the number of years since the establishment of the firm. Foreign $n_{i t-1}$ is a binary variable taking values 1 if the firm has foreign capital participation, and 0 otherwise. $\rho_{j}$ are 2-digit industry fixed-effects for each of the 20 manufacturing sectors described in Table 2 and control for differences across sectors in terms of product markets, technology, demand characteristics and other common sectoral effects. The estimated results can thus be interpreted as within sector effects. Finally, $\eta_{t}$ denotes year fixed effects that control for the macro effects described in the empirical model (13), such as aggregate exchange rate effects in the data as well as any other macroeconomic shifts. All time varying regressors are lagged one period to avoid potential simultaneity problems. ${ }^{9}$

Although the empirical model given by Eq. (15) is static, a large body of empirical evidence suggests that sunk exporting costs induce persistence in the firm exporting decision and that past export experience by the firm may influence future export decisions (e.g. Campa 1998; Das et al. 2007; Máñez et al. 2008). To account for this possibility Equation (16) includes the lagged export status of the firm $Y_{i t-1}$, which equals 1 if firm $i$ exports in the previous year and 0 otherwise. ${ }^{10}$ This measure of experience has been typically interpreted as capturing the importance of sunk costs on export market participation (e.g. Roberts and Tybout 1997). A positive and significant $\phi$ indicates that sunk costs are present, the underlying intuition being that if past export status positively affects the probability to export, then the presence of entry costs induces persistence in export participation. In the empirical results below I compare the results from estimating the two alternative specifications of Eq.(16). The simple period static case, which does not include the past exporting decision $Y_{i t-1}$, and the multi-period dynamic case, which does.

As a baseline regression model I use a random-effect probit, which has been shown by the recent literature to be the best approach to model such binary choice model with unobserved firm heterogeneity (Roberts and Tybout 1997). The advantage of the random-effect probit is that it explicitly controls for firm-unobserved heterogeneity by allowing the error term to be composed by a time-invariant unobserved firm specific effect $u_{i}$ and by a random unobserved shock $\omega_{i t}$ that varies both across firms and time. However, it has been suggested that the use of the random-effect probit may come at a cost if the firmspecific effects $u_{i}$ are correlated with the regressors (Bernard and Jensen 2004). To show that the baseline results are robust to alternative estimation techniques in the sensitivity analysis presented below I will

\footnotetext{
${ }^{9}$ The results are robust to alternative specifications where the explanatory variables are lagged two periods. These results are available from the author upon request.

${ }^{10}$ By including only one lag of the export status variable, I assume that firms completly loose their sunk start-up costs if they are absent from market 1 year. This is in line with previous empirical evidence suggesting that sunk start-up costs depreciate very quickly and that firms that most recently exported 2 years ago have to pay nearly as much to re-renter foreign markets as first time exporters (Das et al. 2007; Máñez et al. 2008; Roberts and Tybout 1997).
} 
also present results from the following alternative methods proposed by the recent literature. First, from probit and linear probability models with robust standard errors clustered at the firm-level. Clustering is an alternative approach to deal with firm unobserved heterogeneity because it controls for the fact that observations for the same firm are related over time (Greenaway et al. 2007). And second, I will also present results from a linear probability model with fixed-effects. The advantage of the fixed-effect linear probability model is that it does not require the firm effects $u_{i}$ to be uncorrelated with the regressors. However, it suffers from some known shortcomings, such as non-normal distributed error terms or nonsensical predictions that can create the predicted values to come outside the zero and one range (Green 2008). ${ }^{11}$

\subsection{Identification of Innovation Measures}

The choice of innovation measures is motivated by the previous literature described in the introduction and the richness of the dataset. The advantage of the dataset is that it includes not only information on the firm-level innovation inputs but also on direct outputs from the innovation process. Regarding the inputs, the survey annually asks firms whether or not they conducted $R \& D$ activities in a given year. ${ }^{12}$ I label this variable $R \mathscr{E} D$ dummy, which takes the value 1 whenever the firm replied yes to the question and 0 whenever it replied no. In addition the dataset includes information on the total R\&D expenditures of firms, which allows to compute a more conventional measure of innovation inputs represented by $R \mathscr{E} D$ intensity, which is measured as the ratio of total R\&D spending (internal and contracted) over total sales of each firm in a given year.

The dataset is unique in that it also includes information on introduction of process and product innovation that I can use to measure innovation outputs and to investigate the differential effect of each type of innovation on the firm export participation. In particular, it includes information on whether or not the firm introduced a process innovation in a given year, represented by the implementation of a new or significantly improved production process, and whether or not the firm introduced a product innovation, that is the introduction of a good that is new or significantly improved with respect to its characteristics or intended uses. ${ }^{13}$ Based on this information I construct dummy variables process innovation and product innovation, which take values 1 when the firm introduced innovations and 0 when not.

Process innovations allow firms to reduce marginal costs and to gain a cost advantage over competitors. Process innovations can be intended to decrease unit costs of production or delivery, to increase quality or to produce a new significantly improved product. An illustration of a process innovation may shed light on the difference between process and product innovations. For instance, a well-known process innovation in the retail industry is the introduction of just-in-time manufacturing capabilities by Inditex, an Spanish clothing company. By introducing this system of well coordinated logistics and vertical integration Inditex has been able to reduce costs and adjust fast to changes in market trends, which has led the firm to gain an edge over its competitors in foreign markets (Guillén 2005). This example fits well the economic intuition from the theoretical model: by improving its production process an innovator can reduce its costs, charge a lower price than its competitors and be more likely to enter foreign markets because it

\footnotetext{
${ }^{11}$ Some of the known shortcomings of the linear probability model are: non-normal errors, non-constant error variance, non-linearity and non-sensical predictions that can create predicted values that are not bounded between zero and one. For further insights into the advantages of the probit model versus the linear probability model see Green (2008).

${ }^{12}$ The definition of research and development $(R \& D)$ used by the ESEE survey is the standard international definition as given by the Frascati Manual. I verified that all the firms that answered yes to the question whether they conducted R\&D activities in a given year also reported some positive $R \& D$ expenditures.

${ }^{13}$ The process innovation variable takes value 1 if the firm says that it has introduced a process innovation (new machinery, new organization methods, or both) during the survey year. Following this definition, the introduction of a process innovation may be the result of imitation. Evidence by Huergo and Jaumandreu (2004) using the same dataset however shows that firms tend not to report changes which are generalised in the market as innovative productive modifications.
} 
can reap higher profits than firms that do not innovate.

A firm can also gain a competitive edge in the export market by introducing a new product. Firms can increase the demand for their products through product differentiation, by targeting new markets and by influencing demand for new products. An example of this is the case of Freixenet, a Spanish producer of sparkling wines. In the late eighties Freixenet wanted to export cava to the US, the largest export market for sparkling wines. After substantial market research Freixenet identified a market niche in the mid-quality market segment and developed a new cava, the "Cordón Negro" or black bottle. The new product was intended to appeal to young American professionals and was specially developed by Freixenet to penetrate the US market (Guillén 2005). In line with this illustration, the introduction of a product innovation is expected to positively affect the probability of exporting if firms upgrade their products to meet foreign demand preferences and market conditions. Iacovone and Javorcik (2008) find empirical evidence supporting this casual observation using data from Mexican plants. They find that firms upgrade the quality of their products preceding an expansion into foreign markets. Bernard and Jensen $(1999,2004)$ further suggest that product upgrading may increase the probability of exporting if the product attributes determine the firm decision to export.

\section{$5 \quad$ Empirical Results}

This section describes the empirical results and provides the sensitivity analysis to validate the accuracy and consistency of the baseline results. I first discuss the baseline results obtained through the estimation of Eq. (16) using a random-effects probit. In the sensitivity analysis, I focus on the main econometric issues discussed in the previous literature (e.g. Bernard and Jensen 2004; Das et al. 2007; Grossman and Helpman 1991) to provide the results that are robust with respect to alternative econometric methods and the potential endogeneity between firm's exporting and innovation.

\subsection{Baseline Regression Results on Innovation and Exporting}

Table 5 presents the baseline results obtained through estimation of Eq. (16) using a random-effects probit. The columns in Table 5 refer individually to different input and output measures of innovation. The first four columns report the results for the simple period case, where sunk entry costs are not explicitly modelled and left out as unobserved firm characteristics. And the last four columns report the results for the multi-period case, which includes the lagged export status as explanatory variable. The results confirm the hypothesis that innovative firms are more likely to export in both versions of the empirical model, the simple period static version and the dynamic multi-period one. The coefficients on innovation are positive and strongly significant at the 1 percent level for all specifications, regardless of the proxy used to measure innovative activity.

\section{[Insert Table 5]}

The variables of main interest are the measures of innovative activities of firms. On the one hand, I estimate the role of inputs into the innovation process. Following directly the theoretical model the decision to innovate is captured by a dichotomus variable taking value 1 if a firm reports $R \& D$ activity and 0 if it does not. As predicted by theory, the coefficient on the R\&D dummy variable is positive and highly significant at the 1 percent level, given in columns (1) and (5). This result suggests that the firms with R\&D activities are more likely to export. In particular, the result in columns (2) and (6) shows that the probability to export increases with the R\&D intensity of an average firm.

On the other hand, I capture the role of different outputs from the innovation process. The coefficient on the process innovation dummy is positive and highly significant at the 1 percent level, given columns 
(3) and (7). A firm that has introduced process innovations during the last year is on average more likely to export in the current year than a non-innovating firm. The point estimate implies that introducing cost-reducing process innovations on average increases the export probability by about 3 percentage points, given columns (3) and (7) of Table 5. This result confirms the hypothesis of the theoretical model that the firms which introduce cost-reducing innovations are more likely to export.

Similarly, the statistically significant coefficient on the product innovation dummy suggests a positive effect of introducing product innovation on the probability of exporting in the next period, as given by columns (4) and (8) of Table 5. The corresponding point estimates imply that introducing product innovations today would increase the probability of exporting tomorrow by about 4 to 7 percentage points. This result suggests that the firms producing upgraded products are more likely to serve foreign markets as they produce goods, which appear to be adapted to foreign market characteristics or demand preferences. This result is in line with the findings of Bernard and Jensen (2004) for the US suggesting that product attributes affect the firm decision to enter foreign markets.

With regard to the other firm-level determinants of exporting, the results are consistent with those found in the previous literature for countries other than Spain (see Greenaway and Kneller (2007) for a literature review). The first result, is that size, as measured by the log of total employment, always has a positive significant effect on the probability of exporting. This result indicates the importance of scale-effects on exporting as suggested by the trade literature on scale-economy based exporting. ${ }^{14}$ Second, the positive and significant estimates on the age variable indicate that older firms are more likely to export. Studies of industrial evolution suggest that efficient producers are more likely to survive and grow, so age may be picking-up the efficiency differences across producers. ${ }^{15}$

Third, the positive and significant effect of the foreign-ownership dummy suggests that foreignowned firms are more likely to export than domestically owned firms. This result is in line with the literature on multinational firms suggesting that subsidiaries of foreign firms will find it easier to penetrate foreign markets because they can take advantage of the intra-industry distribution channels and contacts (Markusen 2002). Finally, the positive and highly significant coefficient on TFP suggests that more productive firms are also more likely to export, which is consistent with the theoretical model in Section 2 and depicted by Figure 1. This result suggests more productive firms self-select into foreign markets, which is in line with the empirical findings of Bernard and Jensen (1999; 2004) for the US and other authors for a wide set of developed and developing countries discussed in the introduction.

The results from the dynamic model show that past exporting matters for the firm current decision to export, as reflected by the positive and significant coefficient of the lagged dependent variable at the bottom of Table 5, columns (5) to (8). As discussed above this suggests that firms face costs associated with entering foreign markets which appear to be sunk in nature. The point estimates of the lagged export dummy measuring the size of the sunk costs are large, about 0.80, and in line with the previous evidence reported by Campa (1998) and Máñez et al. (2008). These coefficients suggest that current exporters are $80 \%$ more likely to export next year than non-exporters. Comparing the effect of innovation on exporting in the simple period static case to the multi-period dynamic case, the effect of innovation is slightly smaller in the dynamic model when proxied by the innovation dummy and R\&D intensity, and slightly larger when proxied by the process and product innovation dummies.

The above results are in line with the theoretical model showing that innovating firms are more likely to export. Moreover, the results reveal the heterogeneous effects of different types of innovation on the firm export participation. Firms that introduce a product innovation are between $4 \%$ and $7 \%$ more likely

\footnotetext{
${ }^{14}$ This literature suggests that acess to larger markets increases the efficiency of firms as they can exploit scale economies. There are several papers that investigate the scale effects of opening-up to trade among others, for example, Trefler (2004) analyzes the effects of the Canada-US Free Trade Agreement on the efficiency of Canadian firms.

${ }^{15}$ For a review of the empirical literature on firm dynamics see Barteslman and Dom (2000). In particular for Spain, Fariñas and Ruano (2005) show that continuing firms are systematically more efficient than exiting and new firms.
} 
to export next period than firms that do not innovate, while firms that improve their production process are 3\% more likely to export than those that do not innovate. The slightly stronger effect of product innovation on exporting may be due to the fact that product upgrading is often a necessary step for firms to serve foreign markets. Firms typically need to adjust their products to foreign market standards and regulations. Furthermore, as shown by Iacovone and Javorcik (2008), firms may also improve the quality of their products to differentiate from competitors and better meet consumer preferences. On the other hand, improvements in the production process give cost-advantage to firms, but these advantages may take longer time to manifest and to give advantages to firms in various ways such as price cuts, higher markups or increased survival probability.

\subsection{Sensitivity Analysis}

This section shows that the baseline results are robust with respect to alternative econometric approaches and not sensitive to the potential endogeneity between innovation and exporting using instrumental variables and the GMM Arellano Bond (1991) estimator.

\subsubsection{Alternative Econometric Methods}

Table 6 shows that the baseline results are robust with respect to alternative econometric methods used to estimate equation (16). As discussed above, the recent literature proposes several econometric methods to estimate such a binary choice model with unobserved firm heterogeneity as the one described by equation (16) (e.g. Bernard and Jensen 2004; Greenaway et al. 2007). Each row in Table 6 reports the results from alternative regression methods for the simple period static model (columns (1)-(4)), and the multi-period dynamic model (columns (5) to (8)). Row (1) gives the results from a probit model with robust standard errors clustered at the firm-level, while row (2) and row (3) give the results from a linear probability model with clustered errors at the firm level, and from a fixed-effect linear probability model respectively. The table focuses on the estimates of the innovation variables of interest to facilitate the discussion on the sensitivity of the results to alternative regression methods.

\section{[Insert Table 6]}

The effect of innovation on the probability of exporting is positive and highly significant at the $1 \%$ across the four different innovation measures when using the probit and the linear probability model with clustered errors at the firm-level in rows (1) and (2) of Table 6. The evidence from a positive and significant effect from innovation on exporting is weaker if the estimation method includes fixed effects. In the simple period case, the results from the R\&D dummy and the process innovation dummy confirm a positive and significant effect of innovation on exporting, columns (1) and (3) of Table 6. However, when proxied by $R \& D$ intensity and the product innovation dummy innovation does not affect exporting, columns (2) and (4). In the multi-period case, only the process innovation has a positive and significant effect on exporting (column (7)), while the other three innovation proxies do not significantly affect exporting, columns (5), (6) and (8). One possible explanation for the weaker significance of the results when controlling for firm fixed-effects may be that including fixed-effects in the model over-controls for firm time-invariant characteristics making some of the innovation proxies non-significant. The literature analyzing the innovation activities of firms has shown that firms' innovation activity tends to be highly persistent and that firms that innovate one period tend to innovate once again the next period (e.g. Peters, 2009). In that case the effect of innovation could be picked-up by the firm fixed-effect in the estimation of Eq. (16), which captures firm characteristics that are persistent over time. 


\subsubsection{Addressing Potential Endogeneity Concerns}

It has been argued that exporting firms will be more likely to innovate if, for instance, there is learningby-exporting and exporters are more likely to innovate than domestic firms because they are exposed to knowledge inputs not available to incumbent firms serving the domestic market (e.g. Grossman and Helpman 1991). In what follows I show the results are robust to this endogeneity concern by instrumenting the firm innovation status when estimating the baseline econometric model.

Table 7 reports the results from estimating equation (16) instrumenting firm innovation. The first four columns of Table 7 report the results from the simple-period static case using two stages least squares (2SLS) estimation. Columns 5 to 8 report the results from the multi-period dynamic case using the Arellano Bond (1991) difference GMM estimator. ${ }^{16}$ As an instrument of the firm innovation status, I use a variable measuring whether or not the firm is a recipient of public support for R\&D. Public policies promoting $\mathrm{R} \& \mathrm{D}$ are aimed at increasing firm innovation activities and are unrelated to firms' exporting activities, so they provide a good instrument to measure the exogenous effect of innovation on exporting. Indeed the instrument is significantly correlated with firm-level innovative status (0.51) and uncorrelated with the firm exporting status (0.20). ${ }^{17}$ It is also a sufficiently strong instrument from a statistical point of view, as it provides a good fit in the first stage regressions of the 2SLS and comfortably passes the F-test, as reported in Table 7 .

\section{[Insert Table 7]}

To further address the validity of the instrument, I take a closer look at the composition of firms that have received R\&D subsidies. Blanes and Busom (2004) analyze how R\&D support is allocated between firms and projects in Spain and their research shows that eligibility rules are not restrictive nor biased towards specific groups of firms. Columns (1) to (4) of Table 7 show the results from the second stage 2SLS regression for the simple-period case. The coefficients on the instrumented innovation variables are positive and statistically significant as the baseline results reported in Table 5. The results from the GMM estimation of the multi-period dynamic case are reported in columns (5) to (8). The GMM estimator takes into account the econometric problems that arise when estimating the dynamic version of equation (16) with firm fixed-effects and endogenous explanatory variables. First, in addition to using the exogenous instrument discussed above also includes lagged levels of the endogenous regressors, which makes the endogenous innovation variable predetermined and therefore not correlated with the error term in equation (16). Second, to cope with the problem of the potential correlation between the firm fixed-effects and the explanatory variables, the GMM estimates Eq. (16) in first differences and therefore eliminates the fixed-effect from the estimated equation. And finally, the lagged dependent variable $Y_{i t-1}$ is also instrumented with its past levels to control for the autocorrelation that may arise when including dynamics into the model. The results from the dynamic GMM estimations confirm a positive and highly significant effect of innovation on exporting from Table 5. Because of the clear advantages of the GMM outlined before in the text, I conclude that the positive relationship between innovation and exporting is robust.

\footnotetext{
${ }^{16}$ In the instrumental variables estimations I estimate linear models rather probit models because instrumental variables regressions (IV) within the probit framework require very strong assumptions (See Carrasco (1998) for details on IV estimation in the probit framework).

${ }^{17}$ The variable motivated directly by the theoretical model is the $R \& D$ dummy for which the instrument of public R\&D support is strongly correlated with. Although intuitive and significant in the first stage 2SLS (Table 7, columns 2, 3, and 4), the other three proxies for innovation should be interpreted with caution, because their correlation with the instrument is weaker than for the $R \& D$ dummy.
} 


\section{Conclusion}

This paper evaluates the role of innovation for the firms' participation in the export markets. Building upon the most recent literature, this paper develops a simple theoretical model that links the firm's exporting and innovating activities in support of the empirical analysis. The focus of this paper is primarily empirical with a working hypothesis that innovation has a positive effect on the firm's export decision. Consistent with the model predictions, the results show that previous innovation by firms enhances their probability of exporting.

This finding appears to be robust to alternative specifications and different measures of innovation. An important aspect of this paper is that it explores in detail the Spanish firm-level data on firm-specific innovation. One of the main advantages of our dataset is that it allows an individual treatment of firm's introduction of process and product innovations for a representative panel of Spanish manufacturing firms. After controlling for productivity differences across firms, the results indicate that regardless of the innovation activity considered in the model, the innovating Spanish firms have a higher probability of exporting than non-innovating firms.

A further insight into the innovation activities of firms reveals some interesting issues. When distinguishing between the effects of different types of innovation, the return in terms of future exporting appears to be higher for the firms that introduce product innovations than for the firms that introduce process innovations. There are several possible interpretations. First, product upgrading could give Spanish firms the competitive edge in terms of future probability of exporting compared to the costreducing innovations. Since the main destination market of Spanish firms is the intra-EU market with a relatively high level of product quality and standards, this result indicates that product differentiation seems to be a superior strategy for entering the foreign market than cost-reducing innovation. During the investigation period, Spanish firms had to undergo product upgrading simply to meet the rapidly evolving standards of the EU. Moreover, as suggested by Bernard and Jensen (2004), product upgrading is an important component of firms' strategy to penetrate foreign markets. Consistently, Iacovone and Javorcik (2008) find empirical evidence of product quality upgrading preceding entry into foreign markets for a sample of Mexican plants.

\section{Acknowledgements:}

I am grateful to André Sapir for his support and constructive advice. I also thank Bee Yan Aw, Paola Conconi, Harald Fadinger, Victor Ginsburgh, Georg Kirchsteiger, Nicholas Sheard, Ziga Zarnic, two anonymous referees and seminar participants at ECARES-Université Libre de Bruxelles, the University College London ENTER Jamboree and the CEPR SCIFI-GLOW meeting in Madrid for useful discussions and suggestions. The financial support from the Fundación Ramón Areces and the Université Libre de Bruxelles for acquiring the data is gratefully acknowledged.

\section{References}

[1] Ackerberg, D., Benkard, L., Berry, S. and Pakes, A. (2008). "Econometric Tools for Analyzing Market Outcomes," forthcoming chapter in the Handbook of Econometrics, Volume 6.

[2] Arellano, M. and Bond S. (1991). "Some Tests of Specification for Panel Data: Monte Carlo Evidence and an Application to Employment Equations," Review of Economic Studies, 58, 277-97.

[3] Aw, B. Y. and Hwang A. R. (1995) "Productivity and the Export Market: a Firm Level Analysis," Journal of Development Economics Vol. 47 313-332. 
[4] Aw, B.Y, Roberts, M.J. and Winston T. (2007). "Export Market Participation, Investments in R\&D and Worker Training, and the Evolution of Firm Productivity." The World Economy, Vol. 14, No. 1 , pp.83-104.

[5] Aw, B.Y, Roberts, M.J. and Yi D. Xu (2009). "R\&D Investments, Exporting and Productivity Dynamics," NBER Working Paper 14670.

[6] Bartelsman, E., Doms, M. (2000). "Understanding Productivity: Lessons from Longitudinal Microdata. Journal of Economic Literature 38, 569-594.

[7] Bernard, A. B. and Jensen, J.B. (1995). "Exporters, Jobs, and Wages in US Manufacturing: 19761987," Brooking Papers on Economic Activity: Microeconomics, 67-119.

[8] Bernard, A.B. and Jensen, J.B. (1999). "Exceptional Exporter Performance: Cause, Effect, or Both?," Journal of International Economics 47 (1), 1-25.

[9] Bernard, A.B. and Wagner (2001). "Export Entry and Exit by German Firms," Review of World Economics, 137, 105-123.

[10] Bernard, A.B., Eaton, J., Jensen, B.J. and Kortum, S. (2003). "Plants and Productivity in International Trade," American Economic Review 93 (4), 1268-1290.

[11] Bernard, A.B., Jensen, B.J. (2004). "Why Some Firms Export?" Review of Economics and Statistics $86(2), 561-569$.

[12] Bernard, A.B., . (2007). "Firms in International Trade," Journal of Economic Perspectives 21 (3), 105-130.

[13] Blanes, J.V. and Busom, I. (2004). "Who Participates in R\&D Subsidy Programs? The Case of Spanish Manufacturing Firms," Research Policy vol 33 (10), 1459-1476.

[14] Bustos, P. (2005). "The Impact of Trade on Technology and Skill Upgrading Evidence from Argentina," Universitat Pompeu Fabra mimeo.

[15] Bustos, P. (2009). "Trade Liberalization, Exports and Technology Upgrading: Evidence on the Impact of MERCOSUR on Argentinean Firms," forthcoming The American Economic Review.

[16] Campa, J.M. (1998). "Hysteresis in Trade: How Big Are the Numbers?," Working Paper 9802, Programa de Investigaciones Económicas, Fundación Empresa Pública.

[17] Carrasco, R. (2001). "Binary Choice with Binary Endogenous Regressors in Panel Data: Estimating the Effect of Fertility on Female Labour Participation," Journal of Business and Economics Statistics, American Statistical Association, vol. 19(4), 385-94.

[18] Cassiman, B. and Martínez-Ros, E. (2005). "Product Innovation and Exports: Evidence from Spanish Manufacturing" IESE mimeo.

[19] Clerides, S., Lach S., and Tybout J.R. (1998). "Is Learning By Exporting Important? Micro-Dynamic Evidence From Colombia, Mexico, and Morocco. Quarterly Journal of Economics 113(3), 903-947.

[20] Constantini, J. A. and Melitz, M. (2008). " The Dynamics of Firm-Level Adjustment to Trade Liberalization," CEPR mimeo.

[21] Das, S., Roberts, M.J., Tybout, J.R. (2007). "Market Entry Costs, Producer Heterogeneity, and Export Dynamics," Econometrica 75 (3), 837-873.

[22] Delgado, M., Fariñas J. and Ruano S. (2002), "Firm Productivity and Export Markets: a NonParametric Approach," Journal of International Economics 57,397-422.

[23] De Loecker, J. (2007). "Do Exports Generate Higher Productivity? Evidence from Slovenia," Journal of International Economics 73(1), 69-98.

[24] Dixit, A. (1989). "Entry and Exit Decisions under Uncertainty," Journal of Political Economy 97 (3), 620-638. 
[25] EU KLEMS (2007). "Productivity in the European Union; a Comparative Industry Approach," EU KLEMS Database Project.

[26] Fariñas, J.C. and Jaumandreu J. (1999). "Diez Años de la Encuesta sobre Estrategias Empresariales (ESEE)," Economía Industrial n. 329 pp. 29-42.

[27] Fariñas, J.C. and Martín-Marcos, A. (2007). "Exporting and Economic Performance Firm-Level Evidence From Manufacturing," The World Economy vol 30, No. 4, 618-646.

[28] Fariñas, J.C. and Ruano S. (2005). "Firm Productivity, Heterogeneity, Sunk Costs and Market Selection," International Journal of Industrial Organization 23, 505-534.

[29] Girma, S., Görg H. and Hanley A. (2008). "R\&D and Exporting: A Comparison of British and Irish Firms" Review of World Economics vol. 144, No. 4.

[30] Green, W. (2008). "Econometric Analysis" Prentice Hall, 6th Edition.

[31] Greenaway, D., Guariglia, A. and Kneller R. (2007). "Do Financial Factors Affect Exporting Decisions?" Journal of International Economics, vol 73 (2) 377-395.

[32] Greenaway, D. and Kneller, R. (2007). "Firm Heterogeneity, Exporting and Foreign Direct Investment," The Economic Journal 117, 134-161.

[33] Griliches, Z (1998) "R\&D and Productivity the Econometric Evidence," The University of Chicago Press.

[34] Grossman, G.M., Helpman E. (1991). "Innovation and Growth in the Global Economy," Cambridge, MIT Press.

[35] Guillén, M.F. (2005). "The Rise of Spanish Multinationals, European Business in the Global Economy," Cambridge University Press.

[36] Huergo, E. and Jaumandreu J. (2004). "Firms' Age, Process Innovation and Productivity Growth," International Journal of Industrial Organization 22, 541-559.

[37] Iacovone, L. and Javorcik, S. B. (2008). "Getting Ready: Preparation for Exporting," University of Oxford mimeo.

[38] Klette, T. J., and Griliches Z. (1996). "The Inconsistency of Common Scale Estimators When Output Prices are Unobserved and Endogenous," Journal of Applied Econometrics, 11(4): 343-61.

[39] Konings, J., Vandenbussche, H., (2008). "Heterogeneous responses of firms to trade protection," Journal of International Economics 76, 371-383.

[40] Lileeva, A. and Trefler, D. (2007). "Trade Liberalization Raises Plant-Level Productivity...for Some Plants," NBER Working Paper 13297.

[41] Mairesse, J., Jaumandreu, J. (2005). "Panel Data Estimates of the Production Function and the Revenue Function: What Difference Does it Make?," Scandinavian Journal of Economics, 107, 651672.

[42] Mañez, J.A., Rochina-Barrachina M.E and Sanchis, J.A., (2008). "Sunk Cost Hysteresis in Spanish Manufacturing Exports," Review of World Economics,Vol 144 (2).

[43] Markusen J. R. (2002) "Multinational Firms and the Theory of International Trade," Cambridge MIT Press.

[44] Melitz, M. (2003)." The Impact of Trade on Intra-industry Reallocations and Aggregate Industry Productivity," Econometrica 71(6), 1695-1725.

[45] OECD (2004). "Main Science and Technology Indicators," Volume 2004/2.

[46] Olley, S. and Pakes, A. (1996). "The Dynamics of Productivity in the Telecommunications Equipments Industry," Econometrica 64(6), 1263-1298. 
[47] Peters B. (2009). "Persistence in Innovation: Stylized Facts and Panel Data Evidence," The Journal of Technology Transfer, vol 34 (2), 226-243.

[48] Roberts, M. and Tybout, J. (1997). "The Decision to Export in Colombia: An Empirical Model of Entry with Sunk Costs," American Economic Review 87 (4), 545-564.

[49] Trefler, A. (2004). "The Long and Short of the Canada-U.S. Free Trade Agreement," American Economics Review 94, 870-895.

[50] Van Beveren, I. (2007). "Total Factor Productivity Estimation: A Practical Review," LICOS Discussion Papers 18207, LICOS - Centre for Institutions and Economic Performance, K.U.Leuven.

[51] Van Biesebroeck, J. (2006). "Exporting Raises Productivity in Sub-Saharan African Manufacturing Firms," Journal of International Economics, vol 67 (2), pp. 373-391.

[52] Van Biesebroeck, J. (2007). "Robustness of Productivity Estimates," The Journal of Industrial Economics, vol 55 (3), pp 529-569.

[53] Wagner, J. (2007). "Exports and productivity: A survey of the evidence from firm-level data," The World Economy 30 (1), 60-82.

[54] Yeaple, S.R. (2005). "A Simple Model of Firm Heterogeneity, International Trade, and Wages," Journal of International Economics 65, 1-20. 


\section{Appendix: Data Appendix}

1. Data Cleaning: The data is cleaned from unlikely values, large spikes and missing values according to the following criteria. First, I dropped observations with negative real value added (305 of them). Second, I dropped the observations with unrealistically large spikes: a) Employment growth of more than $200 \%$, when there was no merger in the previous or next year (38). b) Sales growth of more than $500 \%$ when there was no merger in the previous or next year (27). And c) Output growth of more than 500\% when there was no merger in the pervious or next year (18). Third, I dropped firms that exhibit irregular exit patterns. That is firms for which one cannot be certain that they did not exit the sample before it was recorded in the data such as firms that i) do not answer or ii) do not collaborate in the year previous to exit the sample (5). Finally, I dropped observations with export intensity (ratio of exports to sales) larger than 1 (2). As a result of the cleaning process described above, less than $2 \%$ of observations are lost, so the sample remains highly representative of the population of Spanish manufacturing firms.

2. Definition of variables: All variables are measured annually at the firm-level and are taken from the ESEE survey, unless otherwise stated. All monetary variables are in real terms and have been deflated using the appropriate deflators used below.

Age: age in a given year, computed as $\mathrm{t}$ minus the year of birth (as declared in the questionnaire) plus 1 , since firms report the information at the end of the natural year.

Export dummy: equal to 1 if the firms reports positive export sales and 0 otherwise.

Export intensity: export sales over total sales.

Export sales: export sales as reported by the firm. Real exports are calculated deflating nominal values using the firm-specific output deflator described below.

Foreign ownership dummy: equal to 1 if the firm has a foreign participation share of equal to at least $20 \%$ of total capital, and 0 otherwise.

Industry dummies: 20 industry dummies. Each dummy takes the value 1 if the firm main activity is in that industry, and zero otherwise. See Table 2 for the industry breakdown.

$R \mathscr{E} D$ dummy: a dummy equal to 1 when the firm reports to conduct $\mathrm{R} \& \mathrm{D}$ activities and 0 when it reports not to do $R \& D$.

$R E D$ expenditure: total research and development (R\&D) expenditure by the firm, including both intramural and extramural expenditures as defined by the Frascati manual, deflated using the consumer price index.

RED intensity: R\&D expenditure over total sales in percentage.

Product innovation dummy: a dummy equal to 1 when the firm reports to introduce a product innovation, and 0 otherwise. Product innovations are completely new products, or with such modifications that they are different from those produced earlier. For instance, such that it incorporates new materials, new intermediate products, new design, or new functions of the product.

Process innovation dummy: a dummy equal to 1 when the firm reports to introduce a process innovation, and 0 otherwise. For instance, changes in the process such as the introduction of new machinery, new methods of organizing the work, or both.

Public support for innovation dummy: a dummy equal to 1 when the firm reports to have received support for innovation from any public institution, which may include the Spanish central government, the regional governments, or other institutions like the European Union, and 0 otherwise.

Wage: average wage calculated as labor costs over the total number of employees.

Total factor productivity (TFP): is estimated using the Olley and Pakes (1996) employing the following variables. Ouput is measured by the sales minus production costs. Real output is constructed by deflating the nominal value using the firm-specific output deflator described below. Materials are measured by the cost of material inputs. Real material input is constructed deflating the nominal value using the firmspecific material input deflator described below. Capital is measured by total capital assets. Real capital is constructed by deflating the nominal value using the capital deflator described below. Investment is constructed using the perpetual inventory method and the capital variable. Real investment is constructed by deflating the nominal value using the investment deflator described below. And Labor is the number of workers multiplied by the number of hours per worker (normal hours of work plus overtime minus idle working hours).

3. Deflators:

Output deflator: individual price indices for each firm are constructed using the information on output price changes in the firm's main market drawn from the ESEE.

Material input deflator: individual price indices for each firm are constructed using information on the price changes and the costs of material inputs drawn from the ESEE; which include raw materials, energy 
and purchases of external services. The index is then constructed using the formula: $P_{\text {mat }}=\frac{C_{s e r v}}{C_{m a t}} P_{\text {serv }}+$ $\frac{C_{\text {raw+ener }}}{C_{\text {mat }}} P_{\text {raw+ener }}$, where $C_{\text {serv }}$ stands for the cost of external services purchased by the firm, $P_{\text {serv }}$ is the price index of external services, $C_{\text {raw+ener }}$ is the cost of raw materials and energy, $C_{\text {mat }}$ represents the total cost of materials, and $P_{\text {raw+ener }}$ is the price index of raw materials and energy. Since the available data does not allow to distinguish between the relative weight of raw materials and energy, I took the geometric mean of both prices giving fixed weights to each component: $P_{\text {raw }+ \text { ener }}=\left[P_{\text {raw }}\right]^{0.95}\left[P_{\text {ener }}\right]^{0.05}$ following the procedure commonly used by the ESEE survey.

Capital deflator: average annual equipment goods component of the index of industry prices published by the Instituto Nacional de Estadística.

Investment deflator: average annual equipment goods component of the index of industry prices published by the Instituto Nacional de Estadística.

Producer price index (PPI): the gross output price indices at the industry-level are taken from the EU KLEMS database (March, 2007). Since the industrial classification used by the ESEE does not exactly match the one used by the EU KLEMS database, I aggregate from the original 20 sectors in the ESEE to 17. I aggregate sectors: [151]-Production, processing and preserving of meat, [152-158, 160]-Food products and tobacco and [151]-Beverages that are merged together into "Food, Beverages and Tobacco". And sectors [361]-Furniture and [362-633; 371-372]-Other manufacturing into "Manufacturing nec and recycling". The other sectors remain the same. The gross output price indices for the aggregated sectors are constructed by weighting the individual sector indices with their output shares over the aggregated sector output. To compute the weights I use information on gross output at current basic prices from EU KLEMS 2007. For the aggregated sectors, I then use information on gross output at current basic prices from EU KLEMS to compute the shares of the individual sectors over the aggregated sectoral output. Those shares are used to weight each of the individual output price index to obtain an output deflator at the aggregated sector level.

Consumer price index (CPI): average annual general consumer price index published by the Instituto Nacional de Estadística. 
Table 1. Export and innovation patterns in the data

\begin{tabular}{ccccc}
\hline \hline Year & All firms $^{\mathrm{a}}$ & Exporters $^{\mathrm{b}}$ & Innovators $^{\mathrm{c}}$ & R\&D intensity $^{\mathrm{d}}$ \\
\hline 1991 & 2,058 & 1,056 & 772 & $0.75 \%$ \\
1992 & 1,976 & 1,039 & 704 & $0.70 \%$ \\
1993 & 1,869 & 989 & 653 & $0.76 \%$ \\
1994 & 1,876 & 1,053 & 682 & $0.71 \%$ \\
1995 & 1,702 & 1,019 & 610 & $0.68 \%$ \\
1996 & 1,716 & 1,033 & 614 & $0.67 \%$ \\
1997 & 1,920 & 1,188 & 671 & $0.67 \%$ \\
1998 & 1,776 & 1,138 & 677 & $0.72 \%$ \\
1999 & 1,754 & 1,099 & 667 & $0.80 \%$ \\
2000 & 1,870 & 1,218 & 706 & $0.77 \%$ \\
2001 & 1,724 & 1,123 & 633 & $0.73 \%$ \\
2002 & 1,708 & 1,099 & 640 & $0.63 \%$ \\
\hline Average & 1,829 & 1,088 & 669 & $0.72 \%$ \\
\hline
\end{tabular}

Note: ${ }^{a}$ All firms refer to all Spanish manufacturing firms. $-{ }^{\mathrm{b}}$ Exporters are those firms that report positive export sales. ${ }^{\mathrm{c}}-$ Innovators are firms that report positive R\&D expenditures. ${ }^{\mathrm{d}}$ - R\&D intensity is the ratio of total R\&D expenditures to sales calculated across all sectors and firms for each year and is expressed in nominal terms. 
Table 2. Export and innovation participation rates by sector in the data

\begin{tabular}{|c|c|c|c|c|}
\hline \multirow[b]{2}{*}{ Sector } & \multicolumn{2}{|c|}{ Technological classification } & \multirow[b]{2}{*}{ Exporters $^{\mathrm{c}}$} & \multirow[b]{2}{*}{ Innovators $^{\mathrm{d}}$} \\
\hline & Firm level $^{\mathrm{a}}$ & $\mathrm{OECD}^{\mathrm{b}}$ & & \\
\hline 1 Production, processing meat & Low-tech & Low-tech & $52 \%$ & $22 \%$ \\
\hline 2 Food products and tobacco & Low-tech & Low-tech & $49 \%$ & $28 \%$ \\
\hline 3 Beverages & Low-tech & Low-tech & $55 \%$ & $35 \%$ \\
\hline 4 Textiles and wearing apparel & Low-tech & Low-tech & $52 \%$ & $26 \%$ \\
\hline 5 Leather and leather products & Low-tech & Low-tech & $58 \%$ & $23 \%$ \\
\hline 6 Wood and wood products & Low-tech & Low-tech & $41 \%$ & $13 \%$ \\
\hline 7 Pulp, paper and paper products & Low-tech & Low-tech & $68 \%$ & $36 \%$ \\
\hline 8 Publishing and printing & Low-tech & Low-tech & $37 \%$ & $11 \%$ \\
\hline 9 Chemicals and chemical products & High-tech & Medium-high-tech & $79 \%$ & $69 \%$ \\
\hline 10 Rubber and plastic products & Low-tech & Medium-low-tech & $64 \%$ & $36 \%$ \\
\hline 11 Non-metallic mineral products & Low-tech & Medium-low-tech & $50 \%$ & $32 \%$ \\
\hline 12 Basic metals & Low-tech & Medium-low-tech & $83 \%$ & $56 \%$ \\
\hline 13 Fabricated metal products & Low-tech & Medium-low-tech & $52 \%$ & $27 \%$ \\
\hline 14 Machinery and equipment & High-tech & Medium-high-tech & $72 \%$ & $54 \%$ \\
\hline 15 Office machinery, computers & High-tech & High-tech & $75 \%$ & $61 \%$ \\
\hline 16 Electrical machinery and apparatus & High-tech & Medium-high-tech & $62 \%$ & $55 \%$ \\
\hline 17 Motor vehicles, trailers & High-tech & Medium-high-tech & $81 \%$ & $57 \%$ \\
\hline 18 Other transport equipment & High-tech & Medium-high-tech & $70 \%$ & $46 \%$ \\
\hline 19 Furniture & Low-tech & Low-tech & $50 \%$ & $20 \%$ \\
\hline 20 Other manufacturing & Low-tech & Low-tech & $74 \%$ & $28 \%$ \\
\hline Total manufacturing & & & $59 \%$ & $37 \%$ \\
\hline
\end{tabular}

Note: A sector is defined at the 2-digit level in the NACE rev. 1 classification. ${ }^{\text {a }}$ - Sectoral classification based on the firm-level data, a sector is classified as high-tech if the sector's R\&D intensity is equal or above the average $R \& D$ intensity over all manufacturing sectors. ${ }^{b}$ - Sectors are classified according to their technological intensity based on the OECD classification. ${ }^{c}$ - A firm is classified as an exporter if it reports positive export sales. ${ }^{\mathrm{d}}$ - A firm is classified as an innovator if it reports positive $R \& D$ expenditures. 
Table 3. Innovation characteristics of exporters versus non-exporters

\begin{tabular}{|c|c|c|}
\hline \multicolumn{3}{|l|}{ Panel A. Mean characteristics (\%) } \\
\hline & Exporters & Non-exporters \\
\hline \multicolumn{3}{|l|}{ Average 1991-2002 } \\
\hline $\begin{array}{l}\text { R\&D dummy (yes }=1, \text { no }=0) \\
\text { R\&D intensity } \\
\text { Product innovation dummy (yes }=1, \text { no }=0) \\
\text { Process innovation dummy }(\text { yes }=1, \text { no }=0 \text { ) }\end{array}$ & $\begin{array}{c}53 \\
0.83 \\
36 \\
43 \\
\end{array}$ & $\begin{array}{c}13 \\
0.25 \\
13 \\
23 \\
\end{array}$ \\
\hline \multicolumn{3}{|l|}{1991} \\
\hline $\begin{array}{l}\text { R\&D dummy (yes }=1, \text { no }=0) \\
\text { R\&D intensity } \\
\text { Product innovation dummy (yes }=1, \text { no }=0) \\
\text { Process innovation dummy }(\text { yes }=1, \text { no }=0 \text { ) }\end{array}$ & $\begin{array}{c}58 \\
1.04 \\
37 \\
47 \\
\end{array}$ & $\begin{array}{c}16 \\
0.41 \\
17 \\
26 \\
\end{array}$ \\
\hline \multicolumn{3}{|l|}{1997} \\
\hline $\begin{array}{l}\text { R\&D dummy (yes }=1, \text { no }=0) \\
\text { R\&D intensity } \\
\text { Product innovation dummy (yes }=1, \text { no }=0) \\
\text { Process innovation dummy }(\text { yes }=1, \text { no }=0 \text { ) }\end{array}$ & $\begin{array}{c}49 \\
0.78 \\
36 \\
43 \\
\end{array}$ & $\begin{array}{c}12 \\
0.16 \\
14 \\
25 \\
\end{array}$ \\
\hline \multicolumn{3}{|l|}{2002} \\
\hline $\begin{array}{l}\text { R\&D dummy (yes }=1, \text { no }=0) \\
\text { R\&D intensity } \\
\text { Product innovation dummy (yes }=1, \text { no }=0) \\
\text { Process innovation dummy }(\text { yes }=1, \text { no }=0)\end{array}$ & $\begin{array}{c}52 \\
0.62 \\
33 \\
38 \\
\end{array}$ & $\begin{array}{c}11 \\
0.19 \\
8 \\
16 \\
\end{array}$ \\
\hline \multicolumn{3}{|l|}{ Panel B. Regression analysis } \\
\hline Firm characteristic & \multicolumn{2}{|c|}{$(1)^{\mathrm{b}}$} \\
\hline R\&D dummy (yes $=1$, no $=0$ ) & \multicolumn{2}{|c|}{$0.150 * * *$} \\
\hline$R \& D$ intensity & \multicolumn{2}{|c|}{$0.190 * * *$} \\
\hline Product innovation dummy (yes $=1$, no $=0$ ) & \multicolumn{2}{|c|}{$0.130 * * *$} \\
\hline Process innovation dummy $(\mathrm{yes}=1, \mathrm{no}=0$ ) & \multicolumn{2}{|c|}{$0.065^{* * *}$} \\
\hline Number of employees & \multicolumn{2}{|c|}{$1.581 * * *$} \\
\hline Total factor productivity (TFP) & \multicolumn{2}{|c|}{$0.065^{* * *}$} \\
\hline Wage & \multicolumn{2}{|c|}{$0.117 * * *$} \\
\hline Sales per worker & \multicolumn{2}{|c|}{$0.409 * * *$} \\
\hline Capital per worker & \multicolumn{2}{|c|}{$0.399 * * *$} \\
\hline Observations & \multicolumn{2}{|c|}{16,090} \\
\hline
\end{tabular}

Note: Panel B presents the results from estimating the exporter premia equation (12) over the years 1991-2002. *** indicate significance at the $1 \%$ level. ${ }^{\text {a }}$ - Measures the $\%$ difference between exporters and non-exporters. ${ }^{\mathrm{b}}$ - Reports the coefficients for the basic specification of Equation (12) where the dependent variable is the firm characteristic $(\mathrm{Z})$ and the explanatory variable is a binary variable taking the value 1 when a firm exports and zero otherwise. All the regressions include a control for the number of employees, except for the employment regression. All firm characteristics are in logs except the dummy variables and the ratios. All monetary variables are in real terms, deflated by the appropriate deflator. 
Table 4. Production Function Estimates for the Computation of Total Factor Productivity (TFP)

\begin{tabular}{|c|c|c|c|c|c|c|c|c|c|}
\hline \multicolumn{2}{|r|}{ Sector } & \multicolumn{2}{|c|}{ Observations } & \multicolumn{2}{|c|}{ Labor coefficient } & \multicolumn{2}{|c|}{ Capital coefficient } & \multicolumn{2}{|c|}{ Materials coefficient } \\
\hline & & $\mathrm{N}$ & $\mathrm{N}^{*}$ & OLS & $\mathrm{OP}$ & OLS & $\mathrm{OP}$ & OLS & $\mathrm{OP}$ \\
\hline 1 & Production, processing and preserving of meat & 554 & 370 & 0.473 & 0.401 & 0.037 & 0.062 & 0.505 & 0.517 \\
\hline 2 & Food products and tobacco & 1.928 & 1.245 & 0.213 & 0.189 & 0.064 & 0.090 & 0.715 & 0.695 \\
\hline 3 & Beverages & 405 & 258 & 0.720 & 0.727 & 0.079 & 0.164 & 0.300 & 0.343 \\
\hline 4 & Textiles and wearing apparel & 1.884 & 1.145 & 0.457 & 0.404 & 0.065 & 0.082 & 0.445 & 0.445 \\
\hline 5 & Leather and leather products & 479 & 255 & 0.341 & 0.212 & 0.065 & 0.103 & 0.483 & 0.576 \\
\hline 6 & Wood and wood products & 475 & 280 & 0.564 & 0.349 & 0.074 & 0.052 & 0.414 & 0.515 \\
\hline 7 & Pulp, paper and paper products & 544 & 343 & 0.396 & 0.271 & 0.087 & 0.115 & 0.545 & 0.539 \\
\hline 8 & Publishing and printing & 990 & 582 & 0.546 & 0.534 & 0.058 & 0.058 & 0.458 & 0.422 \\
\hline 9 & Chemicals and chemical products & 1.369 & 863 & 0.444 & 0.502 & 0.081 & 0.094 & 0.514 & 0.478 \\
\hline 10 & Rubber and plastic products & 1.057 & 683 & 0.512 & 0.460 & 0.050 & 0.049 & 0.486 & 0.529 \\
\hline 11 & Non-metallic mineral products & 1.353 & 850 & 0.476 & 0.395 & 0.074 & 0.053 & 0.494 & 0.543 \\
\hline 12 & Basic metals & 628 & 429 & 0.265 & 0.223 & 0.096 & 0.113 & 0.640 & 0.638 \\
\hline 13 & Fabricated metal products & 1.688 & 1.018 & 0.461 & 0.391 & 0.052 & 0.022 & 0.503 & 0.506 \\
\hline 14 & Machinery and equipment & 1.44 & 896 & 0.498 & 0.482 & 0.017 & 0.051 & 0.505 & 0.503 \\
\hline $15-16$ & Office machinery and electrical machinery & 1.719 & 1.081 & 0.519 & 0.480 & 0.016 & 0.061 & 0.538 & 0.545 \\
\hline 17 & Motor vehicles, trailers & 908 & 608 & 0.431 & 0.396 & 0.033 & 0.108 & 0.552 & 0.572 \\
\hline 18 & Other transport equipment & 436 & 287 & 0.416 & 0.337 & 0.017 & 0.062 & 0.568 & 0.583 \\
\hline 19 & Furniture & 870 & 519 & 0.475 & 0.410 & 0.023 & 0.029 & 0.558 & 0.553 \\
\hline 20 & Other manufacturing & 415 & 248 & 0.531 & 0.476 & 0.042 & 0.047 & 0.489 & 0.517 \\
\hline
\end{tabular}

Notes: Estimates of Eq. (13) using OLS and the Olley and Pakes (1996) method denoted OP. Estimates of the production function at the industry level (2 digit) for the period 1991-2002 controlling for time effects using year dummies. The dependent variable is gross output and the explanatory variables are labor, capital and materials. $\mathrm{N}$ refers to the number of observations of the OLS estimations. $\mathrm{N}^{*}$ is the number of observations for the OP estimation and is the one from the first stage of the estimation procedure. 
Table 5. Baseline results: Effect of innovation on export status, random effect probit

\begin{tabular}{|c|c|c|c|c|c|c|c|c|}
\hline \multicolumn{9}{|c|}{ Dependent variable: Export status of firm $i$ at $t$} \\
\hline \multirow[b]{2}{*}{ Variable $^{\mathrm{a}}$} & \multicolumn{4}{|c|}{ Simple-period case } & \multicolumn{4}{|c|}{ Multi-period case } \\
\hline & $\begin{array}{c}\text { R\&D } \\
\text { dummy } \\
(1)\end{array}$ & $\begin{array}{c}\text { R\&D } \\
\text { intensity } \\
(2)\end{array}$ & $\begin{array}{c}\text { Process } \\
\text { innovation } \\
\text { dummy } \\
(3) \\
\end{array}$ & $\begin{array}{c}\text { Product } \\
\text { innovation } \\
\text { dummy } \\
(4) \\
\end{array}$ & $\begin{array}{c}\text { R\&D } \\
\text { dummy } \\
(5) \\
\end{array}$ & $\begin{array}{c}\mathrm{R} \& \mathrm{D} \\
\text { intensity } \\
(6)\end{array}$ & $\begin{array}{c}\text { Process } \\
\text { innovation } \\
\text { dummy } \\
(7) \\
\end{array}$ & $\begin{array}{c}\text { Product } \\
\text { innovation } \\
\text { dummy } \\
(8) \\
\end{array}$ \\
\hline Innovation measure $t$ - 1 & $\begin{array}{c}0.085 \\
(0.013)^{* * *}\end{array}$ & $\begin{array}{c}0.007 \\
(0.003)^{* * *}\end{array}$ & $\begin{array}{c}0.030 \\
(0.009)^{* * *}\end{array}$ & $\begin{array}{c}0.040 \\
(0.010)^{* * *}\end{array}$ & $\begin{array}{c}0.079 \\
(0.013)^{* * *}\end{array}$ & $\begin{array}{c}0.010 \\
(0.003)^{* * *}\end{array}$ & $\begin{array}{c}0.033 \\
(0.011)^{* * *}\end{array}$ & $\begin{array}{c}0.066 \\
(0.012)^{* * *}\end{array}$ \\
\hline Control variables & & & & & & & & \\
\hline Log total employment $t$ - 1 & $\begin{array}{c}0.205 \\
(0.017)^{* * *}\end{array}$ & $\begin{array}{c}0.222 \\
(0.018)^{* * * *}\end{array}$ & $\begin{array}{c}0.215 \\
(0.018)^{* * * *}\end{array}$ & $\begin{array}{c}0.216 \\
(0.018)^{* * * *}\end{array}$ & $\begin{array}{c}0.072 \\
(0.005)^{* * *}\end{array}$ & $\begin{array}{c}0.081 \\
(0.005)^{* * * *}\end{array}$ & $\begin{array}{c}0.078 \\
(0.005)^{* * *}\end{array}$ & $\begin{array}{c}0.079 \\
(0.005)^{* * *}\end{array}$ \\
\hline Log age $t-1$ & $\begin{array}{c}0.057 \\
(0.011)^{* * *}\end{array}$ & $\begin{array}{c}0.060 \\
(0.012)^{* * * *}\end{array}$ & $\begin{array}{c}0.061 \\
(0.011)^{* * * *}\end{array}$ & $\begin{array}{c}0.060 \\
(0.011)^{* * * *}\end{array}$ & $\begin{array}{c}0.011 \\
(0.007)^{*}\end{array}$ & $\begin{array}{c}0.012 \\
(0.007)^{*}\end{array}$ & $\begin{array}{c}0.013 \\
(0.007)^{* *}\end{array}$ & $\begin{array}{c}0.013 \\
(0.007)^{* *}\end{array}$ \\
\hline $\log \operatorname{TFP}^{\mathrm{b}} t-1$ & $\begin{array}{c}0.049 \\
(0.016)^{* * *}\end{array}$ & $\begin{array}{c}0.054 \\
(0.016)^{* * *}\end{array}$ & $\begin{array}{c}0.049 \\
(0.016)^{* * *}\end{array}$ & $\begin{array}{c}0.049 \\
(0.016)^{* * *}\end{array}$ & $\begin{array}{c}0.029 \\
(0.014)^{* *}\end{array}$ & $\begin{array}{c}0.035 \\
(0.014)^{* *}\end{array}$ & $\begin{array}{c}0.031 \\
(0.014)^{* *}\end{array}$ & $\begin{array}{c}0.030 \\
(0.014)^{* *}\end{array}$ \\
\hline Foreign ownership dummy $t$ - 1 & $\begin{array}{c}0.102 \\
(0.015)^{* * *}\end{array}$ & $\begin{array}{c}0.104 \\
(0.015)^{* * * *}\end{array}$ & $\begin{array}{c}0.101 \\
(0.015)^{* * * *}\end{array}$ & $\begin{array}{c}0.102 \\
(0.015)^{* * * *}\end{array}$ & $\begin{array}{c}0.055 \\
(0.016)^{* * *}\end{array}$ & $\begin{array}{c}0.054 \\
(0.016)^{* * *}\end{array}$ & $\begin{array}{c}0.055 \\
(0.016)^{* * *}\end{array}$ & $\begin{array}{c}0.054 \\
(0.016)^{* * *}\end{array}$ \\
\hline Export status $t-1$ & - & - & - & - & $\begin{array}{c}0.791 \\
(0.007)^{* * * *}\end{array}$ & $\begin{array}{c}0.797 \\
(0.007)^{* * * *}\end{array}$ & $\begin{array}{c}0.797 \\
(0.007)^{* * * *}\end{array}$ & $\begin{array}{c}0.793 \\
(0.007)^{* * *}\end{array}$ \\
\hline Year dummies & Yes & Yes & Yes & Yes & Yes & Yes & Yes & Yes \\
\hline Industry dummies & Yes & Yes & Yes & Yes & Yes & Yes & Yes & Yes \\
\hline Observations & 16,339 & 16,191 & 16,336 & 16,335 & 16,339 & 16,191 & 16,336 & 16,335 \\
\hline
\end{tabular}


Table 6. Sensitivity analysis Section 5.2.1: Results from alternative estimation techniques

\begin{tabular}{|c|c|c|c|c|c|c|c|c|}
\hline \multicolumn{9}{|c|}{ Dependent variable: Export status of firm $i$ at $t$} \\
\hline \multirow[b]{2}{*}{ Variable $^{\mathrm{a}}$} & \multicolumn{4}{|c|}{ Simple-period case } & \multicolumn{4}{|c|}{ Multi-period case } \\
\hline & $\begin{array}{c}\text { R\&D } \\
\text { dummy } \\
\text { (1) }\end{array}$ & $\begin{array}{c}\text { R\&D } \\
\text { intensity } \\
(2)\end{array}$ & $\begin{array}{c}\text { Process } \\
\text { innovation } \\
\text { dummy } \\
\text { (3) }\end{array}$ & $\begin{array}{c}\text { Product } \\
\text { innovation } \\
\text { dummy } \\
\text { (4) }\end{array}$ & $\begin{array}{c}\text { R\&D } \\
\text { dummy } \\
(5)\end{array}$ & $\begin{array}{c}\text { R\&D } \\
\text { intensity } \\
(6)\end{array}$ & $\begin{array}{c}\text { Process } \\
\text { innovation } \\
\text { dummy } \\
(7)\end{array}$ & $\begin{array}{c}\text { Product } \\
\text { innovation } \\
\text { dummy } \\
(8)\end{array}$ \\
\hline \multicolumn{9}{|c|}{ Row 1: RE Probit, clustered errors } \\
\hline Effect of innovation measure $t-1$ & $\begin{array}{c}0.180 \\
(0.016)^{* * *}\end{array}$ & $\begin{array}{c}0.018 \\
(0.005)^{* * *}\end{array}$ & $\begin{array}{c}0.071 \\
(0.012)^{* * *}\end{array}$ & $\begin{array}{c}0.158 \\
(0.014)^{* * *}\end{array}$ & $\begin{array}{c}0.079 \\
(0.012)^{* * *}\end{array}$ & $\begin{array}{c}0.010 \\
(0.332)^{* * *}\end{array}$ & $\begin{array}{c}0.033 \\
(0.011)^{* * *}\end{array}$ & $\begin{array}{c}0.066 \\
(0.012)^{* * *}\end{array}$ \\
\hline Export status $t-1$ & - & - & - & - & $\begin{array}{c}0.791 \\
(0.009)^{* * *}\end{array}$ & $\begin{array}{c}0.797 \\
(0.009)^{* * *}\end{array}$ & $\begin{array}{c}0.797 \\
(0.009)^{* * *}\end{array}$ & $\begin{array}{c}0.793 \\
(0.009)^{* * *}\end{array}$ \\
\hline \multicolumn{9}{|l|}{ Row 2: LPM, clustered errors } \\
\hline Effect of innovation measure $t-1$ & $\begin{array}{c}0.139 \\
(0.014)^{* * * *}\end{array}$ & $\begin{array}{c}0.012 \\
(0.003)^{* * *}\end{array}$ & $\begin{array}{c}0.051 \\
(0.010)^{* * *}\end{array}$ & $\begin{array}{c}0.111 \\
(0.011)^{* * *}\end{array}$ & $\begin{array}{c}0.024 \\
(0.005)^{* * *}\end{array}$ & $\begin{array}{c}0.004 \\
(0.001)^{* * *}\end{array}$ & $\begin{array}{c}0.010 \\
(0.004)^{* * *}\end{array}$ & $\begin{array}{c}0.020 \\
(0.004)^{* * *}\end{array}$ \\
\hline Export status $t-1$ & - & - & - & - & $\begin{array}{c}0.793 \\
(0.008)^{* * *}\end{array}$ & $\begin{array}{c}0.795 \\
(0.008)^{* * *}\end{array}$ & $\begin{array}{c}0.796 \\
(0.008)^{* * *}\end{array}$ & $\begin{array}{c}0.794 \\
(0.008)^{* * *}\end{array}$ \\
\hline \multicolumn{9}{|l|}{ Row 3: LPM, fixed-effects } \\
\hline Effect of innovation measure $t-1$ & $\begin{array}{c}0.015 \\
(0.007)^{* *}\end{array}$ & $\begin{array}{c}0.002 \\
(0.001)\end{array}$ & $\begin{array}{c}0.018 \\
(0.005)^{* * *}\end{array}$ & $\begin{array}{c}0.003 \\
(0.006)\end{array}$ & $\begin{array}{c}0.007 \\
(0.007)\end{array}$ & $\begin{array}{c}0.002 \\
(0.001)\end{array}$ & $\begin{array}{c}0.011 \\
(0.005)^{* *}\end{array}$ & $\begin{array}{c}0.000 \\
(0.005)\end{array}$ \\
\hline Export status $t-1$ & - & - & - & - & $\begin{array}{c}0.339 \\
(0.008)^{* * *}\end{array}$ & $\begin{array}{c}0.340 \\
(0.008)^{* * *}\end{array}$ & $\begin{array}{c}0.338 \\
(0.008)^{* * *}\end{array}$ & $\begin{array}{c}0.338 \\
(0.008)^{* * * *}\end{array}$ \\
\hline Controls as in Table $5^{\mathrm{D}}$ & Yes & Yes & Yes & Yes & Yes & Yes & Yes & Yes \\
\hline Year Effects & Yes & Yes & Yes & Yes & Yes & Yes & Yes & Yes \\
\hline Industry Effects ${ }^{\mathrm{c}}$ & Yes & Yes & Yes & Yes & Yes & Yes & Yes & Yes \\
\hline Observations & 16,339 & 16,191 & 16,336 & 16,335 & 16,339 & 16,191 & 16,336 & 16,335 \\
\hline
\end{tabular}

Note: ***,**, indicate significance at the $1 \%, 5 \%$ and $10 \%$ level. RE Probit refers to random effects probit. LPM refers to linear probability model. Robust standard errors are reported in parentheses, and when indicated clustered at the firm-level. All regressions include a constant. The coefficients of the probit model are marginal effects and represent the change in probability due to a one-standard deviation increase in the independent variable at the means of the other variables (or the change from 0-1 in the case of a dummy variable). ${ }^{\mathrm{a}}$ - Estimates from equation (16). ${ }^{\mathrm{b}}-$ The control variables are: $\log$ of total employment, $\log$ of age, log of total factor productivity (TFP), foreign ownership dummy, all lagged one period. ${ }^{\mathrm{c}}$ - The fixed effects models don't include industry dummies and the foreign ownership dummy. 
Table 7. Sensitivity analysis Section 5.2.2: Addressing Potential Endogeneity Concerns

\begin{tabular}{lccccccccc}
\hline \hline Dependent variable: Export status of firm $i$ at $t$ & \multicolumn{3}{c}{} & & & & & & \\
\hline
\end{tabular}


Figure 1. Productivity distributions for different groups of firms in 2002

Panel A
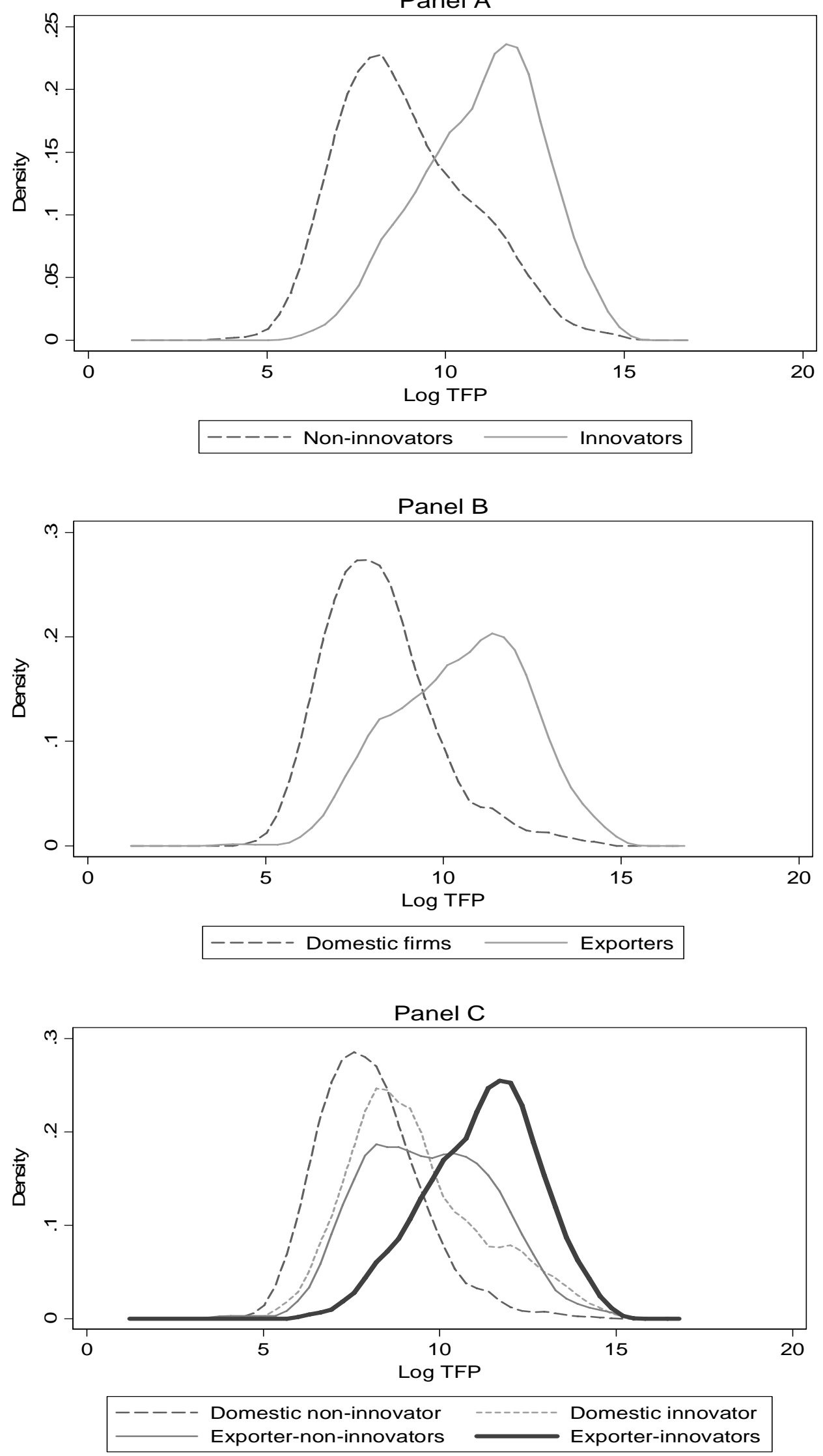

Note: All graphs are Kernel distributions of mean values of the log weighted (by firm output over the total in each firm sector) total factor productivity in 2002, the last year of the sample. 